\title{
Model study of multiphase DMS oxidation with a focus on halogens
}

\author{
R. von Glasow ${ }^{1,2}$ and P. J. Crutzen ${ }^{2,3}$ \\ ${ }^{1}$ Institute for Environmental Physics, Universität Heidelberg, Im Neuenheimer Feld 229, 69120 Heidelberg, Germany \\ ${ }^{2}$ Center for Atmospheric Sciences, Scripps Institution of Oceanography, University of California, San Diego, La Jolla, CA, \\ 92093-0221, USA \\ ${ }^{3}$ Atmospheric Chemistry Division, Max-Planck-Institut für Chemie, PO Box 3060, 55020 Mainz, Germany
}

Received: 26 October 2003 - Published in Atmos. Chem. Phys. Discuss.: 18 December 2003

Revised: 17 March 2004 - Accepted: 22 March 2004 - Published: 14 April 2004

\begin{abstract}
We studied the oxidation of dimethylsulfide (DMS) in the marine boundary layer (MBL) with a onedimensional numerical model and focused on the influence of halogens. Our model runs show that there is still significant uncertainty about the end products of the DMS addition pathway, which is especially caused by uncertainty in the product yield of the reaction of the intermediate product methyl sulfinic acid (MSIA) with $\mathrm{OH}$. BrO strongly increases the importance of the addition branch in the oxidation of DMS even when present at mixing ratios smaller than $0.5 \mathrm{pmol} \mathrm{mol}^{-1}$. The inclusion of halogen chemistry leads to higher DMS oxidation rates and smaller DMS to $\mathrm{SO}_{2}$ conversion efficiencies. The DMS to $\mathrm{SO}_{2}$ conversion efficiency is also drastically reduced under cloudy conditions. In cloudfree model runs between 5 and 15\% of the oxidized DMS reacts further to particulate sulfur, in cloudy runs this fraction is almost $100 \%$. Sulfate production by $\mathrm{HOCl}_{\mathrm{aq}}$ and $\mathrm{HOBr}_{\mathrm{aq}}$ is important in cloud droplets even for small $\mathrm{Br}^{-}$deficits and related small gas phase halogen concentrations. In general, more particulate sulfur is formed when halogen chemistry is included. A possible enrichment of $\mathrm{HCO}_{3}^{-}$in fresh sea salt aerosol would increase $\mathrm{pH}$ values enough to make the reaction of $\mathrm{S}(\mathrm{IV})^{\star}\left(=\mathrm{SO}_{2}\right.$, aq $\left.+\mathrm{HSO}_{3}^{-}+\mathrm{SO}_{3}^{2-}\right)$ with $\mathrm{O}_{3}$ dominant for sulfate production. It leads to a shift from methyl sulfonic acid (MSA) to non-sea salt sulfate (nss-SO ${ }_{4}^{2-}$ ) production but increases the total nss- $\mathrm{SO}_{4}^{2-}$ only somewhat because almost all available sulfur is already oxidized to particulate sulfur in the base scenario. We discuss how realistic this is for the MBL. We found the reaction $\mathrm{MSA}_{\mathrm{aq}}+\mathrm{OH}$ to con-

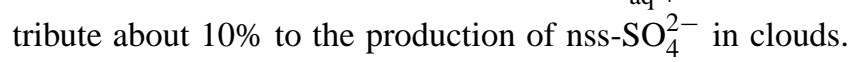
It is unimportant for cloud-free model runs. Overall we find that the presence of halogens leads to processes that decrease the albedo of stratiform clouds in the MBL.
\end{abstract}

Correspondence to: R. von Glasow

(Roland.von.Glasow@iup.uni-heidelberg.de)

\section{Introduction}

Clouds are essential for our climate, not only for their role in the hydrological cycle but also for their influence on the global albedo, i.e. the amount of sunlight that is reflected back to space. The albedo of the ocean is between 0.06 and 0.1 (depending on wind speed), the type of clouds that we focus on in this study - stratocumulus clouds - has an albedo of about 0.6 (e.g. Barry and Chorley, 1998), implying a tenfold change from cloud-free to cloudy conditions. Therefore knowledge about the processes that lead to cloud formation and that influence the albedo is essential to understand short term forcing of climate. Clouds grow on cloud condensation nuclei $(\mathrm{CCN})$ and their number, size, and composition determines cloud albedo (e.g. Twomey, 1974). Over clean oceans CCN are mainly sea salt and sulfate aerosols, with sulfate aerosols usually being dominant in number. Stratiform clouds (stratocumulus, stratus) in clean regions with low $\mathrm{CCN}$ concentrations are most susceptible to changes in size and number of $\mathrm{CCN}$ because of small vertical velocities and supersaturations compared to more convective clouds. This type of cloud covers most of the time between $20 \%$ and $40 \%$ of the oceans at all latitudes (see Lelieveld et al., 1989, for seasonal and latitudinal data).

The most important gaseous precursor for sulfate aerosol over the oceans is dimethyl sulfide (DMS), (see e.g. Charlson et al., 1987) which is produced by organisms in the oceans and subsequently emitted to the atmosphere where it is oxidized via two main reaction pathways: addition of an $\mathrm{O}$ atom and abstraction of an $\mathrm{H}$ atom. $\mathrm{OH}$ both adds to and abstracts from DMS. Contrary to abstraction, addition has a negative activation energy implying higher rates at lower temperatures. $\mathrm{NO}_{3}$ abstracts, but is mainly important in winter under clean marine conditions because of the small $\mathrm{NO}_{\mathrm{x}}$ mixing ratios. Barnes et al. (1991) found in laboratory experiments that $\mathrm{BrO}$ also adds to DMS. Based on this, Toumi (1994) investigated in a model study the importance of $\mathrm{BrO}$ 


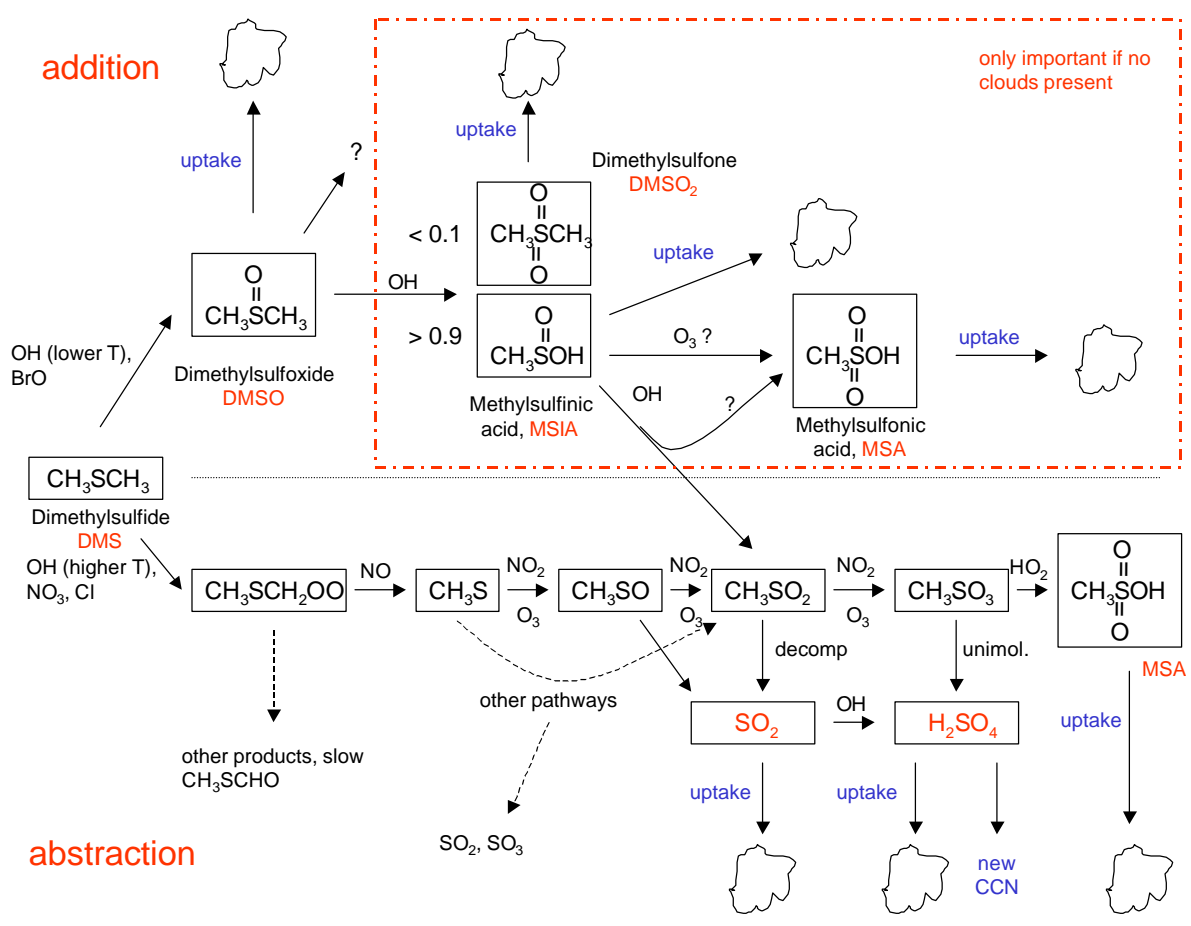

Fig. 1. Schematic of the DMS oxidation reactions in the gas phase as used in this study. Uncertain reactions are denoted with a question mark, dashed pathways are given only for reference and are not included in the model.

as a sink for DMS:

$\mathrm{BrO}+\mathrm{DMS} \longrightarrow \mathrm{DMSO}+\mathrm{Br}$

$\mathrm{He}$ found that for $\mathrm{BrO}$ mixing ratios of $0.5 \mathrm{pmol} \mathrm{mol}^{-1}$ the effect was already significant compared to the $\mathrm{OH}$ reactions. The rate coefficient for this reaction was measured again by Bedjanian et al. (1996), Ingham et al. (1999), and Nakano et al. (2001). The latter two groups extended the measurements to higher pressures and found the reaction rate coefficient to be about $60 \%$ faster than measured by Barnes et al. (1991). We use the value of Ingham et al. (1999) with $\mathrm{k}(\mathrm{BrO}+\mathrm{DMS})=2.54 \times 10^{-14} \exp (850 / T)$. The ultimate fate of the sulfur atom of the dimethyl sulfoxide (DMSO) that is formed in the inital addition reaction is still not completely known (see Sect. 4).

Even though a lot of progress has been made, there are still significant gaps in our knowledge of the kinetics of iodine chemistry. Iodine oxide (IO) adds to DMS as well, the rate coefficient was measured to be significantly slower than that of BrO. Recent laboratory measurements (Nakano et al., 2003), however, indicate a higher rate coefficient under atmospheric pressures. Iodine is also linked to the chemistry of the other halogens and potentially also very important for the loss of ozone (Vogt et al., 1999; McFiggans et al., 2000; von Glasow et al., 2002a), so that there is a need for future studies including the reaction IO+DMS and further updated kinetic information.
Under atmospheric conditions sulfuric acid $\left(\mathrm{H}_{2} \mathrm{SO}_{4}\right)$ is the only final product of the DMS oxidation that can form new aerosol particles, all other products may only condense onto (and thereby enlarge) existing particles (see Fig. 1 for an overview of the DMS oxidation reactions in the gas phase that are used in this study). The distinction between $\mathrm{H}_{2} \mathrm{SO}_{4}$ and other final products is important for chemistry-cloudclimate feedback considerations because of changes in the number and size of CCN. Figure 2 shows the aqueous phase reaction mechanism used in this study. According to Ross et al. (1998), the product of the reaction $\mathrm{DMS}_{\mathrm{aq}}+\mathrm{OH}_{\mathrm{aq}}$ is the adduct. We assumed that addition and abstraction (the latter with the product $\mathrm{HSO}_{4}^{-}$) take place with equal yields. We could show, however, that this reaction is negligible.

In this paper we discuss the results from our numerical model calculations of the oxidation of DMS in the MBL. We investigate several scenarios (different chemical initial conditions; summer vs. winter; cloud-free vs. cloudy) and focus on the differences between the two main oxidation branches, the production of particulate sulfur, and point to possible links between the natural cycles of sulfur and halogens. The halogens chlorine and bromine in the marine boundary layer (MBL) originate from sea salt aerosol and can be released to the gas phase where they also play a role in the destruction of ozone (Sander and Crutzen, 1996; Vogt et al., 1996); see also von Glasow and Crutzen (2003) for an overview.

In Sect. 2 we describe possible links between the cycles of sulfur and halogens and the potential climate importance. 


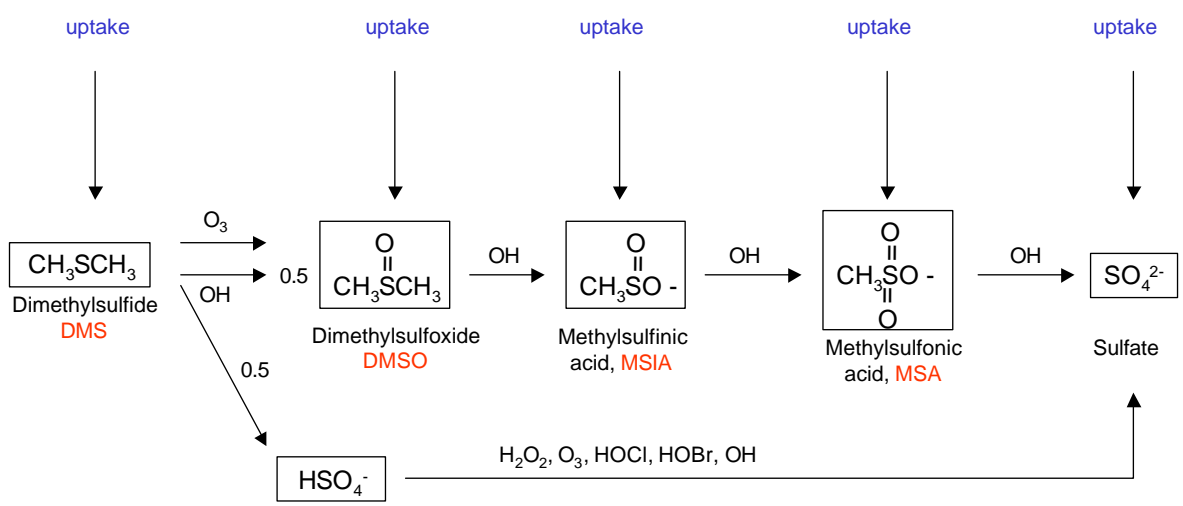

Fig. 2. Schematic of the DMS oxidation reactions in the aqueous phase as used in this study.

In Sect. 3 we give a description of the numerical model that we used for this study and discuss our findings in detail in Sect. 4.

\section{Possible feedbacks between sulfur and halogens}

Halogens interact with sulfur in the MBL in two ways: in the gas phase, mainly by the addition reaction $\mathrm{DMS}+\mathrm{BrO} \longrightarrow \mathrm{DMSO}$ and in the aqueous phase by production of sulfate: $\mathrm{HOX}_{\mathrm{aq}}+\mathrm{S}(\mathrm{IV}) \longrightarrow \mathrm{S}(\mathrm{VI})(\mathrm{X}=\mathrm{Cl}, \mathrm{Br}$, Vogt et al., 1996). The yield of $\mathrm{SO}_{2}$ in the addition branch of the DMS oxidation is smaller than in the abstraction branch, especially under cloudy conditions (see Sect. 4). Reduced gas phase concentrations of $\mathrm{SO}_{2}$ and $\mathrm{H}_{2} \mathrm{SO}_{4}$ lead to a reduction of the precursors for new particle formation because all other intermediate products from the addition branch (dimethylsulfoxide (DMSO), dimethylsulfone ( $\mathrm{DMSO}_{2}$ ), methyl sulfinic acid (MSIA, $\mathrm{CH}_{3} \mathrm{~S}(\mathrm{O}) \mathrm{OH}$ ), methyl sulfonic acid (MSA, $\left.\mathrm{CH}_{3} \mathrm{~S}(\mathrm{O})(\mathrm{O}) \mathrm{OH}\right)$ ) do not produce new particles, they can only condense on preexisting ones thereby increasing the size and, for example for dust, organic, or soot aerosol, the hygroscopicity of the CCN.

The additional S(IV) oxidation reactions by $\mathrm{HOX}_{\mathrm{aq}}$ in the aqueous phase (aerosols and droplets) increase the uptake of $\mathrm{SO}_{2}$ from the gas phase, consequently reducing the production of gaseous $\mathrm{H}_{2} \mathrm{SO}_{4}$ and subsequent new particle formation. On the other hand it leads to the growth of already existing particles. Therefore the net effect of the halogen sulfur interactions are i) decreased precursors for new particle formation and ii) increased size and hygroscopicity of the CCN. This constitutes a natural indirect aerosol effect which would decrease the cloud albedo as opposed to the anthropogenic indirect aerosol effect which increases cloud albedo. The feedbacks are schematically shown in Fig. 3. Under cloud-free conditions this idea is to some extend dependent on the rate coefficient and products of the reaction $\mathrm{MSIA}+\mathrm{OH}$ as explained in Sect. 4.1.
As the activation of sea salt bromide is acid catalyzed, one could hypothesize that the importance of the proposed climate feedback process has increased - at least in the regions that are influenced by anthropogenic pollution - since human activity raised the gas phase acidity of the atmosphere through $\mathrm{SO}_{2}$ and $\mathrm{NO}_{\mathrm{x}}$ emissions leading to $\mathrm{H}_{2} \mathrm{SO}_{4}$ and $\mathrm{HNO}_{3}$; it might also be more important in regions with a lot of ship traffic.

So far, no global information about $\mathrm{BrO}$ concentrations in the MBL is available. Significant depletion of bromide from sea salt aerosol, however, was found in many locations (see Sander et al., 2003, for an overview) which is an indicator for active halogen chemistry in the MBL.

We want to stress that the implications of lower $\mathrm{SO}_{2}$ (and therefore $\mathrm{H}_{2} \mathrm{SO}_{4}$ ) yield from the addition path are valid for all addition reactions.

\section{Model description and setup}

We used the one-dimensional model of the marine boundary layer MISTRA-MPIC as described in von Glasow et al. (2002a,b). In addition to dynamics and thermodynamics, it includes a detailed microphysical module that calculates particle growth explicitly and accounts for interactions between radiation and particles. Chemical reactions in the gas phase are considered in all model layers. In cloud-free layers with relative humidity greater than the crystallization humidity, aerosol chemistry is considered in "sulfate" aerosol (dry radius less than $0.5 \mu \mathrm{m}$, initial composition $32 \%\left(\mathrm{NH}_{4}\right)_{2} \mathrm{SO}_{4}$, $64 \% \mathrm{NH}_{4} \mathrm{HSO}_{4}, 4 \% \mathrm{NH}_{4} \mathrm{NO}_{3}$ ) and "sea salt" aerosol (dry radius greater than $0.5 \mu \mathrm{m}$, initial composition like sea water) bins. In cloud layers two additional chemical aqueous phase bins are considered: droplets that grew on sulfate and on sea salt aerosols.

The model includes 138 gas phase (H-O-S-C-N-Br-Cl) reactions that are important for the chemistry of the MBL including halogen chemistry. A comprehensive reaction set with 143 aqueous phase reactions, 12 heterogeneous 


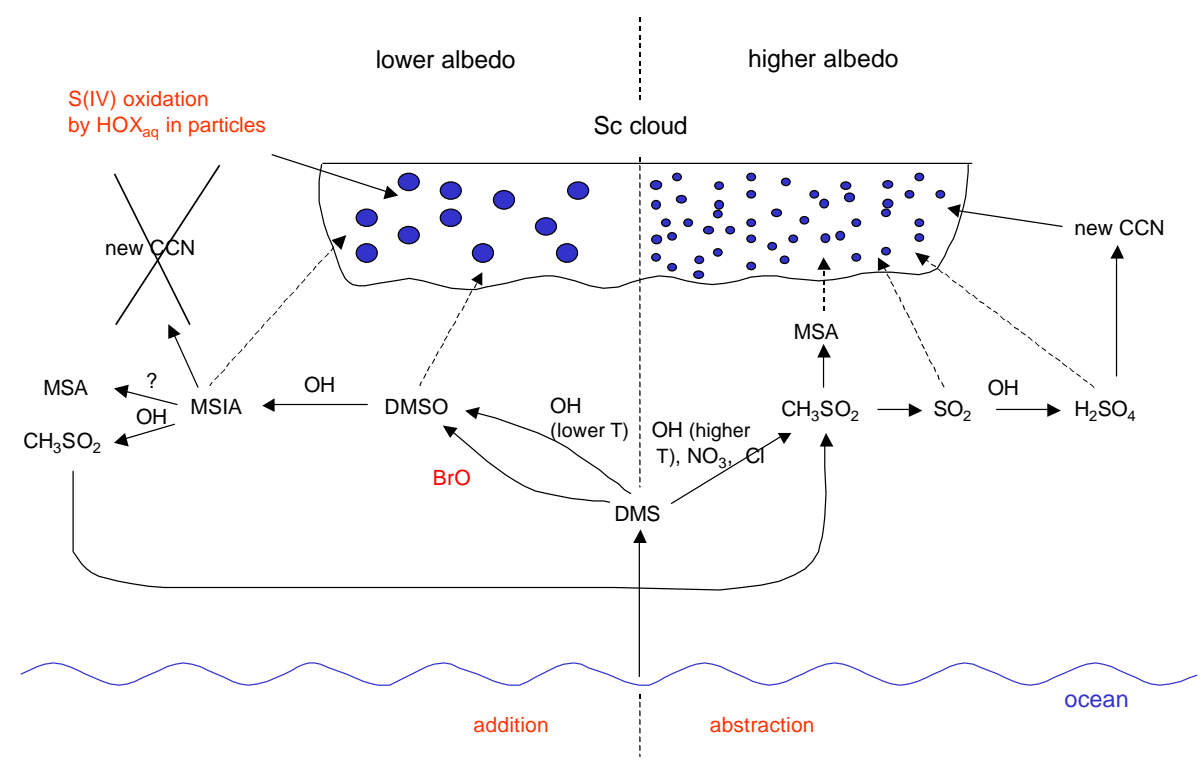

Fig. 3. Schematic of proposed halogen - sulfur - climate links in the MBL.

reactions and 21 equilibria is used for each of the four particulate bins. We updated the DMS oxidation mechanism and treat it in more detail now (see reaction table in electronic attachment to this paper or http://www.rolandvonglasow.de). We assumed that $\mathrm{H}_{2} \mathrm{SO}_{4}$, MSA, MSIA, and $\mathrm{DMSO}_{2}$ have infinite effective Henry's law constant which we implemented by using $\mathrm{H}^{\star}=10^{16} \mathrm{Matm}^{-1}$. If we assume smaller $\mathrm{H}^{\star}$, MSA degasses from the sulfate aerosol during night. The formation of $\mathrm{DMSO}_{2}$ in the reaction $\mathrm{DMSO}+\mathrm{OH}$ is uncertain and reaction of $\mathrm{DMSO}_{2}$ with $\mathrm{OH}, \mathrm{NO}_{3}, \mathrm{O}_{3}$, and $\mathrm{Cl}$ were found to be not of importance (Falbe-Hansen et al., 2000). Our assumption of infinite solubility might overestimate its aqueous fraction which is no major shortcoming in our mechanism, because we assume it to be stable both in the gas and in the aqueous phase, so it only affects the gas-aqueous distribution of an unreactive substance.

The accommodation coefficients for $\mathrm{H}_{2} \mathrm{SO}_{4}$, MSA, MSIA, and $\mathrm{DMSO}_{2}$ are taken from De Bruyn et al. (1994). The initial gas phase concentrations for the different runs are listed in Table 1. In the remainder of this text we will use the generic term "particles" to refer to both aerosols and cloud droplets.

We will discuss detailed process studies of the multiphase chemistry of the MBL under idealized conditions to investigate the reaction mechanism and then show results for "mean" conditions for the tropics and Cape Grim, Tasmania $\left(41^{\circ} \mathrm{S}\right)$.

The latitude chosen for the process studies is $\varphi=30^{\circ} \mathrm{N}$ at the end of July for the summer runs and at the end of January for the winter runs. In the cloud-free runs, the boundary layer height is roughly $700 \mathrm{~m}$, moisture and heat fluxes from the sea surface are adjusted to yield a constant boundary layer height. The relative humidity at the sea surface is roughly
$65 \%$, increasing with height to around $90 \%$ below the inversion that caps the MBL. After a spin-up of the dynamical part of the model for 2 days the complete model was integrated for 5 days (the model runs start at midnight). The surface temperature is about $14^{\circ} \mathrm{C}$ and $3^{\circ} \mathrm{C}$ in the summer and winter runs, respectively. According to Peixoto and Oort (1991) (their Fig. 7.4) the average seasonal difference in surface air temperature over the oceans is less than $10^{\circ} \mathrm{C}$ except for very high latitudes and usually less than $5^{\circ} \mathrm{C}$. Differences between the winter and summer runs are only due to different meteorology, the chemical initial and boundary conditions have not been changed to be able to concentrate on the influence of temperature and insolation. A change in these two parameters, however, does reduce the $\mathrm{OH}$ concentration by $70 \%$ which has major implications for the photochemistry.

For the runs with a stratiform cloud we chose the value of the large scale subsidence such that the cloud top remains stable at $775 \mathrm{~m}$. The cloud base varies between $500 \mathrm{~m}$ during the day and $300 \mathrm{~m}$ during the night. The maximum liquid water content (LWC) is roughly $0.75 \mathrm{~g} / \mathrm{m}^{3}$ before sunrise and $0.45 \mathrm{~g} / \mathrm{m}^{3}$ in the afternoon. In the winter runs the cloud base is fairly constant around $300 \mathrm{~m}$ and the maximum LWC is roughly $0.5 \mathrm{~g} / \mathrm{m}^{3}$. All simulated clouds are non-precipitating. The initial aerosol distribution is listed in Table 2. In the different scenarios we made as few changes to the initial aerosol distribution as possible in order to focus on differences in chemistry and not in microphysics.

For both the cloud-free and cloudy process studies we tested different reaction rates and product yields for the reaction MSIA+OH that is critical for the yields of $\mathrm{SO}_{2}, \mathrm{MSA}$ and $\mathrm{H}_{2} \mathrm{SO}_{4}$ in the addition pathway (see Sect. 4.1).

The MBL height for the "tropics" runs is about $850 \mathrm{~m}$ with a surface temperature of $28^{\circ} \mathrm{C}$. The chemical initial 
Table 1. Initial mixing ratios of gas phase species at the surface (in nmol mol${ }^{-1}$ ) and DMS emissions in $\mathrm{molec}^{-2} \mathrm{~s}^{-1}$.

\begin{tabular}{lrrrr}
\hline species & remote MBL & Cape Grim (summer) & Cape Grim (winter) & tropics \\
\hline $\mathrm{O}_{3}$ & 20.0 & 15.0 & 32.0 & 10.3 \\
$\mathrm{NO}_{2}$ & 0.02 & 0.01 & 0.005 & 0.02 \\
$\mathrm{HNO}_{3}$ & 0.01 & 0.01 & 0.01 & 0.01 \\
$\mathrm{PAN}$ & 0.01 & 0.01 & 0.01 & 0.01 \\
$\mathrm{NH}_{3}$ & 0.08 & 0.04 & 0.02 & 0.08 \\
$\mathrm{H}_{2} \mathrm{O}_{2}$ & 0.6 & 0.7 & 0.1 & 0.6 \\
$\mathrm{SO}_{2}$ & 0.09 & 0.01 & 0.01 & 0.02 \\
$\mathrm{DMS}_{\mathrm{CH}}$ & 0.06 & 0.12 & 0.02 & 0.04 \\
$\mathrm{CO}$ & 1800.0 & 1670.0 & 1690.0 & 1698.0 \\
$\mathrm{C}_{2} \mathrm{H}_{6}$ & 70.0 & 44.0 & 66.0 & 54.8 \\
$\mathrm{HCHO}$ & 0.5 & 0.25 & 0.25 & 0.0 \\
$\mathrm{HCl}$ & 0.3 & 0.3 & 0.3 & 0.2 \\
\hline $\mathrm{DMS}$ emission & 0.04 & 0.01 & 0.005 & 0.02 \\
\hline
\end{tabular}

Values labeled "remote MBL" are for the "generic" runs and are the same for summer and winter runs whereas different values are used for the "Cape Grim" runs in summer and winter. Initial conditions for the "Cape Grim" runs are taken from Ayers et al. (1995, 1997a,b, 1999); Monks et al. (1998, 2000) and initial conditions for the "tropics" run are from Wagner et al. (2002).

Table 2. Initial size distribution of the aerosol.

\begin{tabular}{llll}
\hline mode $i$ & $N_{\text {tot }, i}\left(1 / \mathrm{cm}^{3}\right)$ & $R_{N, i}(\mu \mathrm{m})$ & $\sigma_{i}$ \\
\hline 1 & 100 & 0.027 & 1.778 \\
2 & 120 & 0.105 & 1.294 \\
3a & 6 & 0.12 & 2.818 \\
$3 \mathrm{~b}$ & 7 & 0.2 & 2.512 \\
\hline
\end{tabular}

The data is after Hoppel and Frick (1990). The particle size distribution is calculated according to $\frac{d N(r)}{d \lg r}=\sum_{i=1}^{3} \frac{N_{t o t, i}}{\lg \sigma_{i} \sqrt{2 \pi}} \times \exp \left(-\frac{\left(\lg r-\lg R_{N, i}\right)^{2}}{2\left(\lg \sigma_{i}\right)^{2}}\right)$. Mode 3a was used for all scenarios except the "Cape Grim, summer" scenarios where we used mode $3 \mathrm{~b}$ instead.

conditions are taken from Wagner et al. (2002). We used three scenarios for Cape Grim, namely cloudy winter, cloudy summer, and cloud-free summer trying to get close to observed meteorological conditions but are aware of the fact that this is still only a rough approximation and certainly cannot account for the variability encountered. Like all other scenarios they are mainly meant as sensitivity studies to point to some specific findings. The cloud top in the winter run is at $710 \mathrm{~m}$ and at about $900 \mathrm{~m}$ in the summer run, the cloud base remains roughly around $350 \mathrm{~m}$ in the winter run, whereas it is highest during day with about $650 \mathrm{~m}$ and lowest during night (around $550 \mathrm{~m}$ ) in the summer run. The maximum LWC for both seasons is about $0.4 \mathrm{~g} / \mathrm{m}^{3}$. The surface temperature is about $8^{\circ} \mathrm{C}$ and $14^{\circ} \mathrm{C}$ for the winter and summer runs, respectively. In the cloud-free run the inversion of the MBL is around $700 \mathrm{~m}$, the relative humidity near the sea surface is about $65 \%$ it increases to $95 \%$ at the top of the MBL. Chemical initial conditions for these three runs are from Ayers et al. (1995, 1997a,b, 1999) and Monks et al. (1998, 2000).
In the cloud-free runs we initialized $\mathrm{SO}_{2}$ in the free troposphere with $50 \%$ of the MBL value, whereas we chose $25 \%$ for the cloudy runs. This reduces the downward flux of $\mathrm{SO}_{2}$ in cloudy runs which is both a source of sulfur and of gas phase acidity. Downward transport across the inversion that caps the MBL is small in cloud-free runs.

We included a $\mathrm{NO}_{2}$ source of $10 \mathrm{pmol} \mathrm{mol}^{-1} \mathrm{day}^{-1}$ ( $2 \mathrm{pmol} \mathrm{mol}^{-1} \mathrm{day}^{-1}$ for the "Cape Grim" runs) in order to account for uptake and deposition losses and maintain $\mathrm{NO}_{\mathrm{x}}$ mixing ratios of about 3 and $15 \mathrm{pmol} \mathrm{mol}^{-1}$ for runs with and without halogen chemistry, respectively. Sources for $\mathrm{NO}_{\mathrm{x}}$ in the clean MBL can, for example, be decomposition of ocean derived organic nitrates (e.g. Atlas et al., 1993; Chuck et al., 2002) or direct release from the ocean (Zafiriou et al., 1980).

We did all runs with and without inclusion of halogen chemistry in order to demonstrate the effect of halogens on the chemistry. Under the inital conditions that we chose for the process study runs almost all bromide gets released from the sea salt aerosol resulting in $\mathrm{BrO}$ mixing ratios around 
$1.5 \mathrm{pmol} \mathrm{mol}^{-1}$ during noon and 3-4 $\mathrm{pmol} \mathrm{mol}^{-1}$ during the morning and afternoon peaks (see von Glasow et al., 2002a, for a discussion of the diurnal cycle of $\mathrm{BrO}$ ). In the cloudy process study runs the $\mathrm{BrO}$ mixing ratio is about $1-$ $1.5 \mathrm{pmol} \mathrm{mol}^{-1}$. It is less for the "Cape Grim" and "tropics" scenarios and will be discussed later.

\section{Results and discussion}

The results of the model runs that are discussed in this section are summarized in Tables 3, 4, and 5 which list the DMS oxidation rates, non-sea salt sulfate (nss- $\mathrm{SO}_{4}^{2-}$ ) and MSA production rates, DMS $\rightarrow \mathrm{SO}_{2}$ conversion efficiencies, and MSA to nss $-\mathrm{SO}_{4}^{2-}$ ratios (as explained below). Figures 4 and 5 show the temporal evolution of $\mathrm{SO}_{2}$, DMS, DMSO, MSIA, MSA, and DMSO/DMS and Fig. 6 shows vertical profiles of the same species for noon of the second model day. If not explicitly stated otherwise all numbers that we mention in this section and in the tables refer to mean values over the depth of the MBL and the second to fifth model day for cloud-free runs and second and third day for cloudy runs.

The discussion of the results is subdivided into four parts. In Sect. 4.1 we discuss the likely final products of the addition pathway based on laboratory, field and modeling studies. In Sect. 4.2 we present results from our sensitivity studies for the importance of different pathways in the oxidation of DMS, focussing on halogens. This is followed by a discussion of the particulate final products and related particle growth and a discussion of the conditions encountered in the remote clean marine boundary layer based on Cape Grim, Tasmania and Baring Head, New Zealand conditions (Sect. 4.3). Finally, in Sect. 4.4, we discuss differences in the diurnal variation of particulate and gaseous bromine that could help explain differences that were so far encountered when comparing model and field results.

\subsection{Final products in the addition pathway}

As already mentioned, knowledge about the pathways and product yields of the DMS oxidation is essential to estimate the potential for new particle formation and for growth of existing aerosol particles. Usually it is assumed that MSA is only formed in the abstraction pathway as a product of the reaction $\mathrm{CH}_{3} \mathrm{SO}_{3}+\mathrm{HO}_{2}$. However, MSA might also be formed in the addition pathway. The initial addition reactions produce DMSO which reacts with $\mathrm{OH}$ (Urbanski et al., 1998; Arsene et al., 2002; Wang and Zhang, 2002, almost $100 \%$ yield) to MSIA. Lucas and Prinn (2002) suggested that MSIA might react with $\mathrm{O}_{3}$ to MSA. MSA could also be a product of the reaction MSIA $+\mathrm{OH}$ but the main product of the reaction MSIA+OH is $\mathrm{CH}_{3} \mathrm{SO}_{2}$ (Kukui et al., 2003), a main intermediate in the abstraction pathway. The reaction MSIA+OH could therefore be regarded as a "crossover point" between the addition and abstraction pathway (see also Fig. 1). As will be shown below, the yield of MSA in this reaction and the rate coefficient are of major importance for the determination of the final products of the addition pathway under cloud-free conditions. If most DMSO that is formed in this reaction is transformed via MSIA to $\mathrm{CH}_{3} \mathrm{SO}_{2}$ then there would be no significant differences between the end products of the addition and abstraction pathways in the gas phase. It is important, however, to note that the intermediate products DMSO and MSIA are taken up by particles, especially in the cloudy MBL.

To investigate the possible final products of DMS oxidation and the implications for the MBL, we performed sensitivity studies with different rate constants for the reaction MSIA $+\mathrm{OH}$. Furthermore we investigated different yields of MSA in this reaction and differences between cloud-free and cloudy model runs.

According to the qualitative results of the smog chamber study by Arsene et al. (2002) the overall yield of $\mathrm{SO}_{2}$ in the addition branch should be small, whereas Kukui et al. (2003) found that the yield of $\mathrm{CH}_{3} \mathrm{SO}_{2}$ (a precursor of $\mathrm{SO}_{2}$ ) in the reaction MSIA $+\mathrm{OH}$ is $0.9 \pm 0.2$ with indications for a yield of unity. We used their measurement and previous estimates of the rate constant for the reaction MSIA+OH for sensitivity runs: $\mathrm{k}=1.0 \times 10^{-12} \mathrm{~cm}^{3} \mathrm{molec}^{-1} \mathrm{~s}^{-1}$ (Lucas and Prinn (2002), runs labeled "Luc"), $\mathrm{k}=1.6 \times 10^{-11} \mathrm{~cm}^{3} \mathrm{molec}^{-1} \mathrm{~s}^{-1}$ (Yin et al. (1990), runs labeled "Yin"), $\mathrm{k}=9.0 \times 10^{-11} \mathrm{~cm}^{3} \mathrm{molec}^{-1} \mathrm{~s}^{-1}$ (Kukui et al. (2003), runs labeled "Kuk"). In the cases "Luc" and "Yin" we assumed a $100 \%$ yield of $\mathrm{CH}_{3} \mathrm{SO}_{2}$ from this reaction whereas we tested yields of 0,5 and $10 \%$ MSA for the "Kuk" cases. The "Luc" scenarios also include the reaction $\mathrm{MSIA}+\mathrm{O}_{3}$.

For the "Cape Grim" and "tropics" scenarios we used a yield of 5\% MSA from the reaction MSIA+OH which is well within the experimental uncertainty and increases gas phase MSA mixing ratios.

As already mentioned, we did a model run for each scenario with and without halogen chemistry. In the runs including halogen chemistry the reaction DMS + BrO makes the addition pathway be a lot more important than in runs without halogen chemistry (see Sect. 4.2).

\subsubsection{Model runs for the cloud-free MBL}

In the "Luc" scenario the gas phase concentration of $\mathrm{SO}_{2}$ is reduced by about $30 \%$ when halogen chemistry is considered (see Fig. 4). The production of $\mathrm{SO}_{2}$ is smaller than in the other runs because the "crossing" from the addition to the abstraction pathway via the reaction MSIA+OH is unimportant. In the other runs, especially in the "Kuk" runs, this "crossing" is very efficient and the products $\mathrm{SO}_{2}, \mathrm{H}_{2} \mathrm{SO}_{4}$ and MSA are formed as a consequence in the gas phase. In these runs the $\mathrm{SO}_{2}$ mixing ratio is higher if halogen chemistry is included because of the production of MSIA following the fast reaction DMS+BrO. Only on the last model day, the 
Table 3. Overview of oxidation rates.

\begin{tabular}{|c|c|c|c|c|c|c|c|c|c|c|c|c|}
\hline run & DMS oxidation rate & $\begin{array}{c}\text { relati } \\
\text { oxidat } \\
\mathrm{BrO} \\
\%\end{array}$ & $\begin{array}{l}\text { contribut } \\
\text { on rate } \\
\text { OH(ad) } \\
\%\end{array}$ & $\begin{array}{r}\text { on to tota } \\
\mathrm{OH}(\mathrm{ab}) \\
\%\end{array}$ & $\begin{array}{r}\mathrm{NO}_{3} \\
\%\end{array}$ & nss- $-\mathrm{SO}_{4}^{2-}$ production rate & $\begin{array}{r}\text { relative } \\
\text { product } \\
\mathrm{OH}(\mathrm{g}) \\
\%\end{array}$ & $\begin{array}{l}\text { contributio } \\
\text { on rate } \\
\text { HOX }_{a q} \\
\%\end{array}$ & $\begin{array}{r}0_{3, a q} \\
\%\end{array}$ & $\begin{array}{r}\mathrm{H}_{2} \mathrm{O}_{2, a q} \\
\%\end{array}$ & MSA production rate & $\begin{array}{l}\mathrm{DMS} \rightarrow \mathrm{SO}_{2} \text { con- }- \\
\text { version efficiency }\end{array}$ \\
\hline \multicolumn{13}{|l|}{ cloud-free } \\
\hline Luc & $4.38 \times 10^{-9}$ & 63.4 & 12.7 & 14.7 & 1.2 & $3.31 \times 10^{-10}$ & 38.8 & 50.8 & 1.8 & 8.5 & $1.80 \times 10^{-10}$ & 0.284 \\
\hline Luc, no hal. & $3.49 \times 10^{-9}$ & - & 44.3 & 50.2 & 5.4 & $2.97 \times 10^{-10}$ & 69.0 & - & 10.2 & 20.5 & $1.37 \times 10^{-10}$ & 0.587 \\
\hline Yin & $4.37 \times 10^{-9}$ & 63.6 & 12.6 & 14.6 & 1.2 & $4.91 \times 10^{-10}$ & 43.0 & 45.4 & 1.4 & 10.1 & $0.33 \times 10^{-10}$ & 0.597 \\
\hline Yin, no hal. & $3.49 \times 10^{-9}$ & - & 44.3 & 50.2 & 5.5 & $3.71 \times 10^{-10}$ & 69.3 & - & 9.2 & 21.3 & $0.42 \times 10^{-10}$ & 0.789 \\
\hline Yin, winter & $5.00 \times 10^{-9}$ & 83.5 & 5.5 & 3.1 & 1.2 & $2.19 \times 10^{-10}$ & 11.8 & 74.8 & 7.0 & 6.2 & $0.13 \times 10^{-10}$ & 0.221 \\
\hline Yin, winter, no hal. & $2.54 \times 10^{-9}$ & - & 57.7 & 30.8 & 11.5 & $1.23 \times 10^{-10}$ & 30.6 & - & 52.0 & 16.7 & $0.17 \times 10^{-10}$ & 0.513 \\
\hline Kuk, $0 \%$ MSA & $4.37 \times 10^{-9}$ & 63.8 & 12.5 & 14.5 & 1.3 & $5.87 \times 10^{-10}$ & 46.2 & 41.9 & 1.2 & 10.7 & $0.18 \times 10^{-10}$ & 0.789 \\
\hline Kuk, $0 \%$ MSA, no hal & $3.48 \times 10^{-9}$ & - & 44.3 & 50.2 & 5.6 & $4.18 \times 10^{-10}$ & 69.1 & - & 8.4 & 21.3 & $0.19 \times 10^{-10}$ & 0.905 \\
\hline Kuk, 5\% MSA & $4.37 \times 10^{-9}$ & 63.8 & 12.5 & 14.5 & 1.3 & $5.70 \times 10^{-10}$ & 46.2 & 41.9 & 1.2 & 10.6 & $1.38 \times 10^{-10}$ & 0.762 \\
\hline Kuk, $5 \%$ MSA, no hal. & $3.48 \times 10^{-9}$ & - & 44.3 & 50.2 & 5.6 & $4.15 \times 10^{-10}$ & 68.6 & - & 8.2 & 21.2 & $0.79 \times 10^{-10}$ & 0.888 \\
\hline Kuk, $5 \%$ MSA, winter & $5.01 \times 10^{-9}$ & 83.8 & 5.3 & 2.9 & 1.2 & $2.65 \times 10^{-10}$ & 14.1 & 71.4 & 7.0 & 7.3 & $0.89 \times 10^{-10}$ & 0.406 \\
\hline Kuk, $5 \%$ MSA, winter, no hal. & $2.52 \times 10^{-9}$ & - & 57.6 & 30.8 & 11.6 & $1.36 \times 10^{-10}$ & 31.6 & - & 49.7 & 17.7 & $0.44 \times 10^{-10}$ & 0.653 \\
\hline Kuk, $10 \%$ MSA & $4.38 \times 10^{-9}$ & 63.8 & 12.5 & 14.5 & 1.3 & $5.54 \times 10^{-10}$ & 46.2 & 41.9 & 1.1 & 10.6 & $2.58 \times 10^{-10}$ & 0.734 \\
\hline Kuk, $10 \%$ MSA, no hal. & $3.48 \times 10^{-9}$ & - & 44.3 & 50.2 & 5.6 & $4.09 \times 10^{-10}$ & 68.5 & - & 8.0 & 21.1 & $1.39 \times 10^{-10}$ & 0.871 \\
\hline $\begin{array}{r}\text { tropics } \\
\text { tron, }\end{array}$ & $1.17 \times 10^{-9}$ & 16.9 & 19.6 & 51.0 & 9.5 & $1.77 \times 10^{-10}$ & 89.0 & 8.9 & 0.3 & $\begin{array}{r}1.1 \\
1.7\end{array}$ & $0.20 \times 10^{-10}$ & 0.929 \\
\hline tropics, no hal. & $1.13 \times 10^{-9}$ & - & 24.1 & 62.7 & 13.1 & $1.79 \times 10^{-10}$ & 93.3 & - & 0.3 & 1.8 & $0.14 \times 10^{-10}$ & 0.957 \\
\hline
\end{tabular}

See text for explanation of the different model runs. The numbers are means over the MBL from the 2nd until 5th model day. The contribution of the individual path is given as relative contribution to the total oxidation rate. The main difference between the runs is the rate constant of the reaction MSIA+OH. The following values were chosen: runs labeled "Luc" $-\mathrm{k}=1.0 \times 10^{-12} \mathrm{~cm}^{3} \mathrm{molec}^{-1} \mathrm{~s}^{-1}$ (Lucas and Prinn (2002), also including the reaction MSIA+O 3 ), runs labeled "Yin" $-\mathrm{k}=1.6 \times 10^{-11} \mathrm{~cm}^{3} \mathrm{molec}^{-1} \mathrm{~s}^{-1}\left(\mathrm{Yin}_{\mathrm{n}}\right.$ et al., 1990 ), runs labeled "Kuk" - $\mathrm{k}=9.0 \times 10^{-11} \mathrm{~cm}^{3}$ molec $^{-3} \mathrm{~s}^{-1}$ (Kukui et al., 2003). The percentages given for the "Kuk" runs are the yield of MSA in the reaction MSIA+OH.

Table 4. Overview of oxidation rates, continued.

\begin{tabular}{|c|c|c|c|c|c|c|c|c|c|c|c|c|}
\hline \multirow[b]{3}{*}{ run } & \multirow{3}{*}{$\begin{array}{l}\text { DMS oxidation rate } \\
\qquad\left[\mathrm{mol} \mathrm{m}^{-3} \mathrm{~d}^{-1}\right]\end{array}$} & \multicolumn{4}{|c|}{$\begin{array}{l}\text { relative contribution to total } \\
\text { oxidation rate }\end{array}$} & \multirow{3}{*}{$\begin{array}{l}\text { nss- } \mathrm{SO}_{4}^{2-} \text { production rate } \\
\quad\left[\mathrm{mol} \mathrm{m}^{-3} \mathrm{~d}^{-1}\right]\end{array}$} & \multicolumn{4}{|c|}{$\begin{array}{l}\text { relative contribution to total } \\
\text { production rate }\end{array}$} & \multirow{3}{*}{$\begin{array}{l}\text { MSA production rate } \\
\qquad\left[\mathrm{mol} \mathrm{m}^{-3} \mathrm{~d}^{-1}\right]\end{array}$} & \multirow[t]{3}{*}{$\begin{array}{l}\text { DMS } \rightarrow \mathrm{SO}_{2} \text { con- } \\
\text { version efficiency }\end{array}$} \\
\hline & & $\mathrm{BrO}$ & $\mathrm{OH}(\mathrm{ad})$ & $\mathrm{OH}(\mathrm{ab})$ & $\mathrm{NO}_{3}$ & & $\mathrm{OH}(\mathrm{g})$ & $\mathrm{HOX}_{\mathrm{aq}}$ & $\mathrm{O}_{3, \mathrm{aq}}$ & $\mathrm{H}_{2} \mathrm{O}_{2, \mathrm{aq}}$ & & \\
\hline & & $\%$ & $\%$ & $\%$ & $\%$ & & $\%$ & $\%$ & $\%$ & $\%$ & & \\
\hline $\begin{array}{r}\text { Cape Grim } \\
\text { summer }\end{array}$ & $645 \times 10^{-9}$ & 77.8 & 7. & 107 & 0.8 & $2333 \times 10^{-10}$ & 107 & 40. & 472 & 12 & $2.11 \times 10^{-10}$ & 0700 \\
\hline summer, no hal. & $4.95 \times 10^{-9}$ & - & 39.4 & 56.1 & 4.5 & $21.53 \times 10^{-10}$ & 10.5 & - & 86.8 & 2.0 & $0.94 \times 10^{-10}$ & 0.892 \\
\hline summer, $2.5 \mathrm{x} \mathrm{HCO}_{3}^{-}$ & $5.26 \times 10^{-9}$ & 15.9 & 32.9 & 47.2 & 2.7 & $31.65 \times 10^{-10}$ & 3.2 & 17.6 & 78.5 & 0.4 & $1.08 \times 10^{-10}$ & 0.827 \\
\hline $\begin{array}{r}\text { summer, } 4.5 \times \mathrm{XCO}_{3}^{-} \\
\text {cloudy }\end{array}$ & $4.97 \times 10^{-9}$ & 2.5 & 38.4 & 54.7 & 4.0 & $30.90 \times 10^{-10}$ & 2.3 & 22.4 & 74.8 & 0.3 & $0.95 \times 10^{-10}$ & 0.804 \\
\hline Yin & $3.43 \times 10^{-9}$ & 35.4 & 26.6 & 28.4 & 1.6 & $15.94 \times 10^{-10}$ & 1.4 & 39.4 & 0.7 & 41.0 & $17.66 \times 10^{-10}$ & 0.406 \\
\hline Yin, no hal. & $3.08 \times 10^{-9}$ & - & 40.5 & 43.3 & 9.7 & $19.24 \times 10^{-10}$ & 1.5 & - & 1.4 & 80.6 & $11.66 \times 10^{-10}$ & 0.587 \\
\hline Kuk, $0 \%$ MSA & $3.43 \times 10^{-9}$ & 35.4 & 26.6 & 28.4 & 1.6 & $18.24 \times 10^{-10}$ & 1.7 & 39.0 & 0.7 & 44.6 & $15.12 \times 10^{-10}$ & 0.493 \\
\hline Kuk, $0 \%$ MSA, no hal & $3.08 \times 10^{-9}$ & - & 40.5 & 43.2 & 9.7 & $20.74 \times 10^{-10}$ & 1.6 & - & 1.3 & 82.5 & $9.85 \times 10^{-10}$ & 0.652 \\
\hline Kuk, $5 \%$ MSA & $3.43 \times 10^{-9}$ & 35.4 & 26.6 & 28.4 & 1.6 & $18.03 \times 10^{-10}$ & 1.6 & 38.9 & 0.7 & 44.2 & $15.39 \times 10^{-10}$ & 0.485 \\
\hline Kuk, $5 \%$ MSA, no hal. & $3.08 \times 10^{-9}$ & - & 40.5 & 43.2 & 9.7 & $20.60 \times 10^{-10}$ & 1.6 & - & 1.3 & 82.3 & $10.04 \times 10^{-10}$ & 0.646 \\
\hline Kuk, 5\% MSA, winter & $3.44 \times 10^{-9}$ & 64.0 & 15.5 & 8.6 & 2.1 & $6.65 \times 10^{-10}$ & 0.1 & 54.4 & 1.5 & 27.9 & $21.18 \times 10^{-10}$ & 0.140 \\
\hline Kuk, $5 \%$ MSA, winter, no hal. & $2.01 \times 10^{-9}$ & - & 39.6 & 22.0 & 18.8 & $9.96 \times 10^{-10}$ & 0.2 & - & 4.0 & 68.3 & $10.60 \times 10^{-10}$ & 0.419 \\
\hline $\begin{array}{r}\text { Cape Grim } \\
\text { summer }\end{array}$ & & 38.2 & 29.2 & 29.3 & 1.2 & $15.56 \times 10^{-10}$ & 1.0 & 40.9 & 15.9 & 38.1 & $15.37 \times 10^{-10}$ & 0.451 \\
\hline $\begin{array}{l}\text { summer } \\
\text { summer, no hal. }\end{array}$ & $3.61 \times 10^{-9}$ & $\begin{array}{r}38.2 \\
-\end{array}$ & $\begin{array}{l}29.2 \\
46.0\end{array}$ & $\begin{array}{l}29.5 \\
46.4\end{array}$ & $\begin{array}{l}1.2 \\
5.8\end{array}$ & $22.07 \times 10^{-10}$ & $\begin{array}{l}1.0 \\
1.2\end{array}$ & $\begin{array}{r}40.9 \\
-\end{array}$ & $\begin{array}{l}15.9 \\
33.8\end{array}$ & $\begin{array}{l}38.1 \\
57.9\end{array}$ & $10.65 \times 10^{-10}$ & $\begin{array}{l}0.451 \\
0.644\end{array}$ \\
\hline summer, $2 \mathrm{x} \mathrm{HCO}_{3}^{-}$ & $3.63 \times 10^{-9}$ & 4.6 & 44.2 & 44.5 & 4.5 & $17.57 \times 10^{-10}$ & 0.9 & 22.9 & 39.3 & 31.9 & $11.32 \times 10^{-10}$ & 0.614 \\
\hline summer, $2.5 \mathrm{x} \mathrm{HCO}_{3}^{-}$ & $3.61 \times 10^{-9}$ & 2.5 & 45.0 & 45.4 & 4.9 & $17.73 \times 10^{-10}$ & 0.9 & 21.3 & 45.5 & 27.1 & $11.19 \times 10^{-10}$ & 0.625 \\
\hline summer, $4.5 \mathrm{x} \mathrm{HCO}_{3}^{-}$ & $3.60 \times 10^{-9}$ & 1.3 & 45.5 & 45.9 & 5.2 & $17.88 \times 10^{-10}$ & 0.8 & 17.9 & 51.9 & 23.9 & $11.19 \times 10^{-10}$ & 0.630 \\
\hline winter & $0.13 \times 10^{-9}$ & 15.8 & 13.6 & 8.9 & 40.4 & $0.81 \times 10^{-10}$ & 0.1 & 22.2 & 38.2 & 1.6 & $0.59 \times 10^{-10}$ & 0.499 \\
\hline winter, no hal. & $0.18 \times 10^{-9}$ & - & 7.7 & 5.0 & 77.1 & $1.46 \times 10^{-10}$ & 0.0 & - & 78.5 & 2.6 & $0.30 \times 10^{-10}$ & 0.815 \\
\hline
\end{tabular}

See text and caption of Table 3 for explanation of the different model runs. The numbers are means over the MBL over the 2nd and 3rd model day. The contribution of the individual path is given as relative contribution to the total oxidation rate.

$\mathrm{SO}_{2}$ mixing ratios in the non-halogen runs exceed those of the halogen runs because $\mathrm{OH}$ is needed as reactant which is smaller by roughly $20-25 \%$ on the last model day in the halogen runs due to halogen-catalyzed $\mathrm{O}_{3}$ destruction (see Fig. 5).
The MSA production rate in "Luc" is about five times as high as in the "Yin" runs and ten times greater than in the "Kuk 0\%" runs which is mainly caused by the reaction MSIA $+\mathrm{O}_{3}$. In the "Luc" runs between $61 \%$ and $77 \%$ of $\mathrm{MSA}_{\text {tot }}$ is formed via the reaction $\mathrm{MSIA}+\mathrm{O}_{3}$. Formation 
Table 5. Modeled $\mathrm{P}(\mathrm{MSA})-\mathrm{P}\left(\mathrm{nss}_{-} \mathrm{SO}_{4}^{2-}\right)$ ratios.

\begin{tabular}{|c|c|c|c|c|}
\hline \multirow[b]{2}{*}{ run } & \multicolumn{2}{|c|}{ aerosol } & \multicolumn{2}{|c|}{ droplets } \\
\hline & sulfate & sea salt & sulfate & sea salt \\
\hline \multicolumn{5}{|l|}{ cloud-free } \\
\hline Luc & 0.958 & 0.316 & - & - \\
\hline Luc, no hal. & 0.406 & 0.534 & - & - \\
\hline Yin & 0.064 & 0.071 & - & - \\
\hline Yin, no hal. & 0.068 & 0.187 & - & - \\
\hline Yin, winter & 0.174 & 0.043 & - & - \\
\hline Yin, winter, no hal. & 0.143 & 0.131 & - & - \\
\hline Kuk, $0 \%$ MSA & 0.036 & 0.026 & - & - \\
\hline Kuk, $0 \%$ MSA, no hal. & 0.037 & 0.059 & - & - \\
\hline Kuk, $5 \%$ MSA & 0.402 & 0.125 & - & - \\
\hline Kuk, 5\% MSA, no hal. & 0.201 & 0.167 & - & - \\
\hline Kuk, $5 \%$ MSA, winter & 1.744 & 0.118 & - & - \\
\hline Kuk, 5\% MSA, winter, no hal. & 0.668 & 0.167 & - & - \\
\hline Kuk, $10 \%$ MSA & 0.789 & 0.229 & - & - \\
\hline Kuk, $10 \%$ MSA, no hal. & 0.370 & 0.279 & - & - \\
\hline tropics & 0.115 & 0.115 & - & - \\
\hline tropics, no hal. & 0.016 & 0.157 & - & - \\
\hline CG, summer & 0.632 & 0.033 & - & - \\
\hline CG, summer, no hal. & 0.285 & 0.017 & - & - \\
\hline $\mathrm{CG}$, summer, 2.5x $\mathrm{HCO}_{3}^{-}$ & 0.742 & 0.013 & - & - \\
\hline $\begin{array}{l}\mathrm{CG} \text {, summer, } 4.5 \mathrm{x} \mathrm{HCO}_{3}^{-} \\
\text {cloudy }\end{array}$ & 0.873 & 0.011 & - & - \\
\hline Yin & 0.289 & 0.252 & 1.153 & 0.786 \\
\hline Yin, no hal. & 0.629 & 0.399 & 0.612 & 0.456 \\
\hline Kuk, $0 \%$ MSA & 0.209 & 0.136 & 0.868 & 0.560 \\
\hline Kuk, $0 \%$ MSA, no hal. & 0.540 & 0.273 & 0.478 & 0.363 \\
\hline Kuk, $5 \%$ MSA, & 0.472 & 0.386 & 0.882 & 0.569 \\
\hline Kuk, 5\% MSA, no hal. & 0.643 & 0.389 & 0.484 & 0.366 \\
\hline Kuk, 5\% MSA, winter & 1.429 & 1.062 & 3.307 & 1.178 \\
\hline Kuk, $5 \%$ MSA, winter, no hal. & 0.775 & 0.442 & 1.098 & 0.614 \\
\hline $\mathrm{CG}$, summer & 0.813 & 0.040 & 1.601 & 0.108 \\
\hline CG, summer, no hal. & 0.553 & 0.049 & 0.785 & 0.173 \\
\hline $\mathrm{CG}$, summer, $2 \mathrm{x} \mathrm{HCO}_{3}^{-}$ & 0.857 & 0.017 & 1.672 & 0.050 \\
\hline $\mathrm{CG}$, summer, $2.5 \times \mathrm{HCO}_{3}^{-}$ & 0.894 & 0.016 & 1.878 & 0.044 \\
\hline $\mathrm{CG}$, summer, $4.5 \mathrm{x} \mathrm{HCO}_{3}^{-}$ & 0.952 & 0.018 & 2.048 & 0.050 \\
\hline CG, winter & 0.105 & 0.032 & 1.200 & 0.090 \\
\hline CG, winter, no hal. & 1.174 & 0.006 & 0.062 & 0.015 \\
\hline
\end{tabular}

See text for explanation of the different model runs and $\mathrm{P}(\mathrm{MSA}): \mathrm{P}\left(\mathrm{nss}-\mathrm{SO}_{4}^{2-}\right)$. The values are averaged over the MBL for model days $2-5$ for the cloud-free runs and days $2-3$ for cloudy runs.

of MSA in the reaction $\mathrm{CH}_{3} \mathrm{SO}_{3}+\mathrm{HO}_{2}$ is less than $2.5 \%$ in the summer and about $10 \%$ in the winter runs of the total MSA production for all scenarios. The rest of the $\mathrm{MSA}_{\text {tot }}$ production occurs in the aerosols.

We tested how sensitive the results are to different yields of MSA in the reaction MSIA+OH (only for "Kuk" scenarios). Even a small yield of 5\% leads to a more than sevenfold increase in the formation of MSA because of the high rate constant for MSIA+OH making the gas phase dominant for the formation of total MSA. Using a 10\% yield the MSA production is fourteen times higher.

Reactions of the MSIA-precursor DMSO with compounds other than $\mathrm{OH}$ or strong uptake by particles could make the system less sensitive to the reaction MSIA+OH. We investigated the potential of a surface reaction of $\mathrm{OH}$ with $\mathrm{DMSO}_{\text {surf }}$ because Allen et al. (1999) found that DMSO partitions to the surface in DMSO - water mixtures. We found, however, that almost every $\mathrm{OH}$ molecule that hits the 

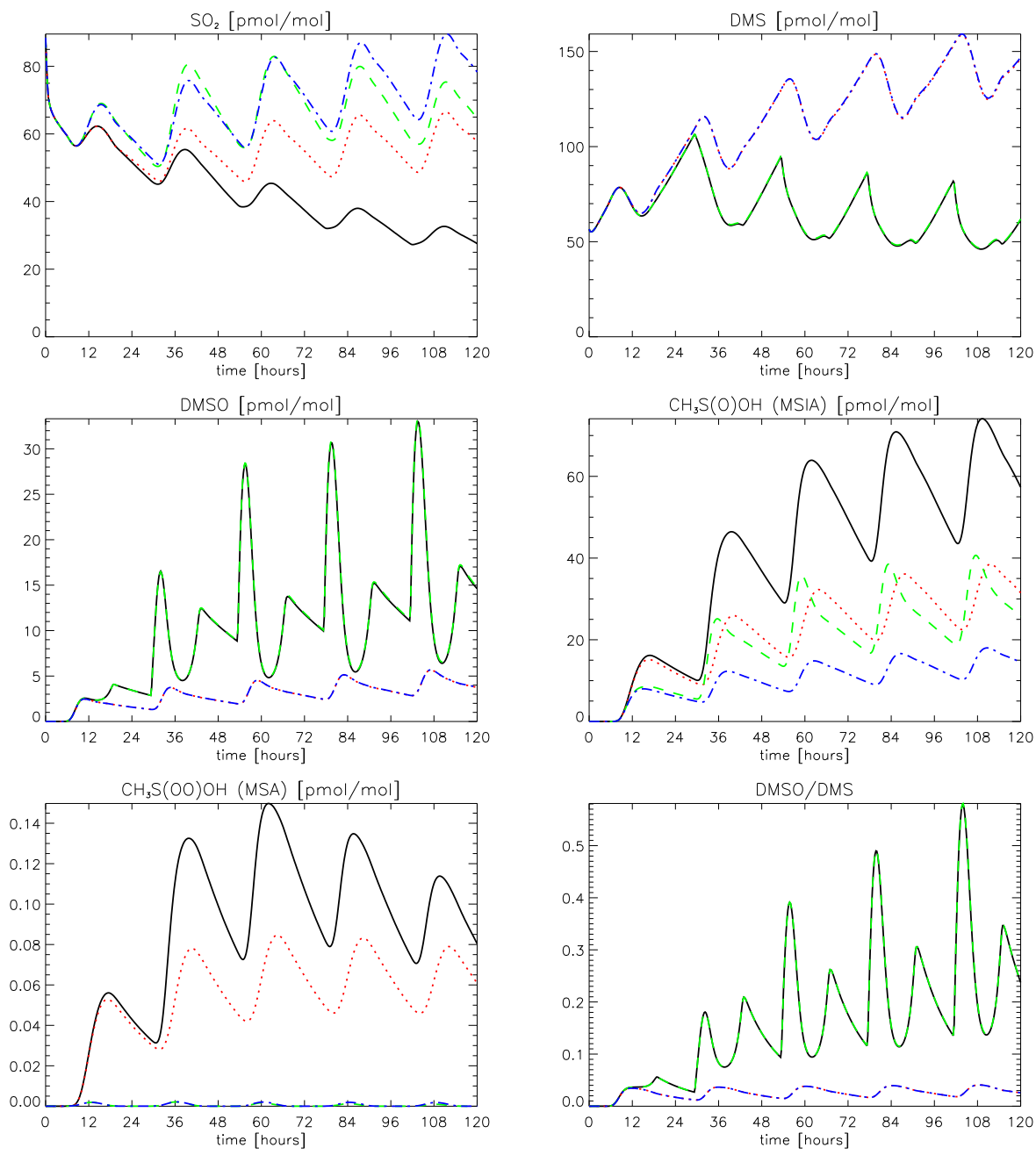

Fig. 4. Temporal evolution in $50 \mathrm{~m}$ altitude of some sulfur species, time is given in hours from modelstart which is at midnight. Results are shown for sensitivity studies with different rate coefficients for the reaction MSIA+OH and with vs. without halogen chemistry. The scenarios are: "Luc" (black, solid line), "Luc, nh" (red, dotted line), "Yin" (green, dashed line), and "Yin, nh" (blue, dash-dotted line), see Sect. 4.1 for an explanation of the abbreviations.

aerosols would have to react with DMSO to lead to a detectable increase in MSIA ${ }^{-}$formation, which is impossible. An upper limit for the aerosol surface fraction being covered with DMSO (based on our size distribution and $\mathrm{DMSO}_{\mathrm{aq}}$ concentrations) is $10^{-4}$. We also tested if aqueous phase reactions of DMSO other than with $\mathrm{OH}$ could lead to an increase in aerosol phase MSA production but both $\mathrm{Cl}_{2}^{-}$and $\mathrm{NO}_{3 \text {, aq }}$ (which have the highest potential to be of importance) could not compete with the $\mathrm{OH}_{\mathrm{aq}}$ reaction. We further tested if increasing the measured Henry's law constant of DMSO (Watts and Brimblecombe, 1987) would lead to an increased production of MSIA ${ }^{-}$via reaction with $\mathrm{OH}_{\mathrm{aq}}$ but this was only the case when we increased it by 3 orders of magnitude, which is unrealistic.

In the "Luc" runs that include MSIA $+\mathrm{O}_{3}$, this reaction is dominant for the production of total MSA (including aerosol). In all cloud-free runs that we discuss in this paper the gas phase production of MSA via $\mathrm{CH}_{3} \mathrm{SO}_{3}+\mathrm{HO}_{2}$ contributes less than $10 \%$ of the total MSA production. For the "Kuk" runs with 5\% yield of MSA the reaction MSIA+OH accounts for more than $70 \%$ of the total MSA production. If these reactions occur as assumed then MSA formation in the DMS abstraction pathway would be only of minor importance unlike usually assumed in the literature so far. The aqueous phase reaction MSIA+ $\mathrm{OH}$ is the main source for total MSA when gas phase production of MSA is unimportant.

The peak mixing ratios of gas phase MSA occur in the model before noon if halogen chemistry is included and at noon for non-halogen model runs (see Sect. 4.2 for an explanation for this). Peak values are less than $1 \times 10^{5} \mathrm{molec}^{-3}$ for the runs with $0 \%$ MSA yield, less than $1.0 \times 10^{7} \mathrm{molec}^{-3}$ for the runs with $5 \%$ MSA yield 

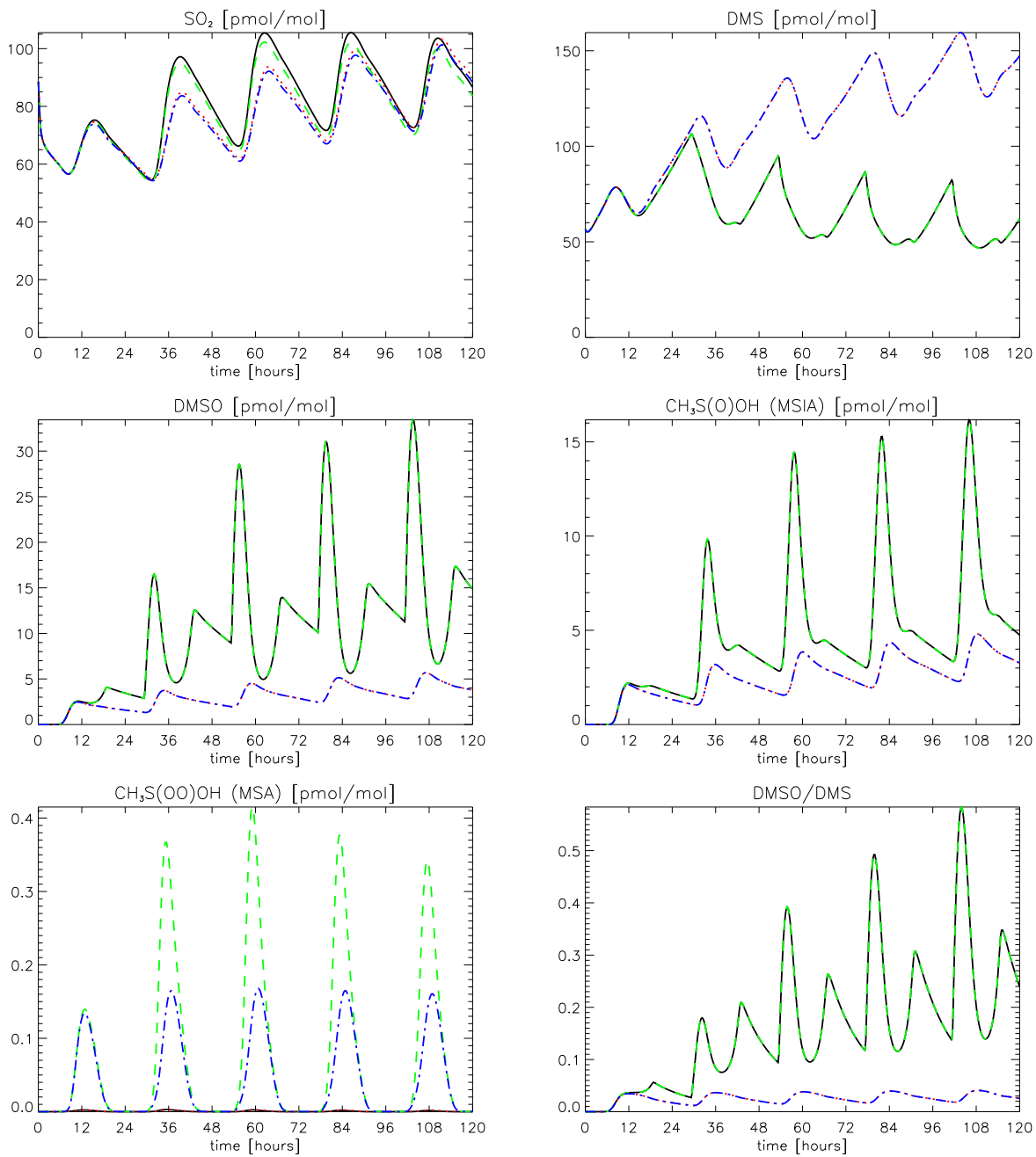

Fig. 5. Same as Fig. 4 but for the scenarios: "Kuk 0\%" (black, solid line), "Kuk 0\%, nh" (red, dotted line), "Kuk 5\%" (green, dashed line), and "Kuk 5\%, nh" (blue, dash-dotted line).

in the reaction MSIA+OH and about $2 \times 10^{7}$ molec $\mathrm{cm}^{-3}$ for the runs with $10 \%$ MSA yield. In our "tropics" scenario with a 5\% yield of MSA the peak concentrations of MSA are

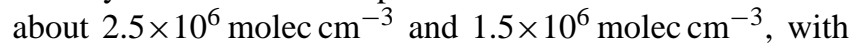
and without halogen chemistry, respectively.

So far only few measurements of gas phase MSA have been made. Published concentrations range from 1$9 \times 10^{5}$ molec $\mathrm{cm}^{-3}$ in the Antarctic (Mauldin et al., 2001; Jefferson et al., 1998), to $10^{5}-10^{6}$ molec $\mathrm{cm}^{-3}$ for the "tropics" (Davis et al., 1999), and $<3 \times 10^{4}-3.7 \times 10^{7}$ molec $\mathrm{cm}^{-3}$ for the Eastern Mediterranean (Bardouki et al., 2003). These measurements indicate that there has to be at least some formation of gas phase MSA in the atmosphere which we could not satisfactorily reproduce in the model without assuming that MSA is produced in the addition pathway.

Davis et al. (1999) estimated that during flight 7 of the PEM Tropics-A campaign the gas phase contributed $1 \%$ to total MSA production. They assumed a MSA yield of $3 \%$ in the reaction $\mathrm{MSIA}+\mathrm{OH}$ and $0.35 \%$ in the abstraction reac- tion of OH with DMS. Lucas and Prinn (2002) concluded that reactions in addition to those proposed by Yin et al. (1990) are needed to reproduce observed MSA(g) during ACE 1. Assuming only the abstraction reaction $\mathrm{DMS}+\mathrm{OH}$ as precursor for $\mathrm{MSA}(\mathrm{g})$, Bardouki et al. (2003) estimated a contribution of the gas phase to total MSA production of $0.1 \%$ for the Eastern Mediterranean Sea.

\subsubsection{Model runs for the cloudy MBL}

Under cloudy conditions the picture changes drastically. The uptake of the MSIA-precursor DMSO into droplets is fast. This leads to a strongly decreased reaction rate of $\mathrm{MSIA}+\mathrm{OH} \longrightarrow \mathrm{CH}_{3} \mathrm{SO}_{2}$ and no significant contribution of the addition pathway to the formation of $\mathrm{SO}_{2}$. Therefore the concentration of $\mathrm{SO}_{2}$ is smaller in all runs including halogen chemistry than in the runs without because of the predominance of addition reactions in the halogen runs. In the "Kuk" scenarios the mean $\mathrm{SO}_{2}$ concentrations are about $12 \%$ 

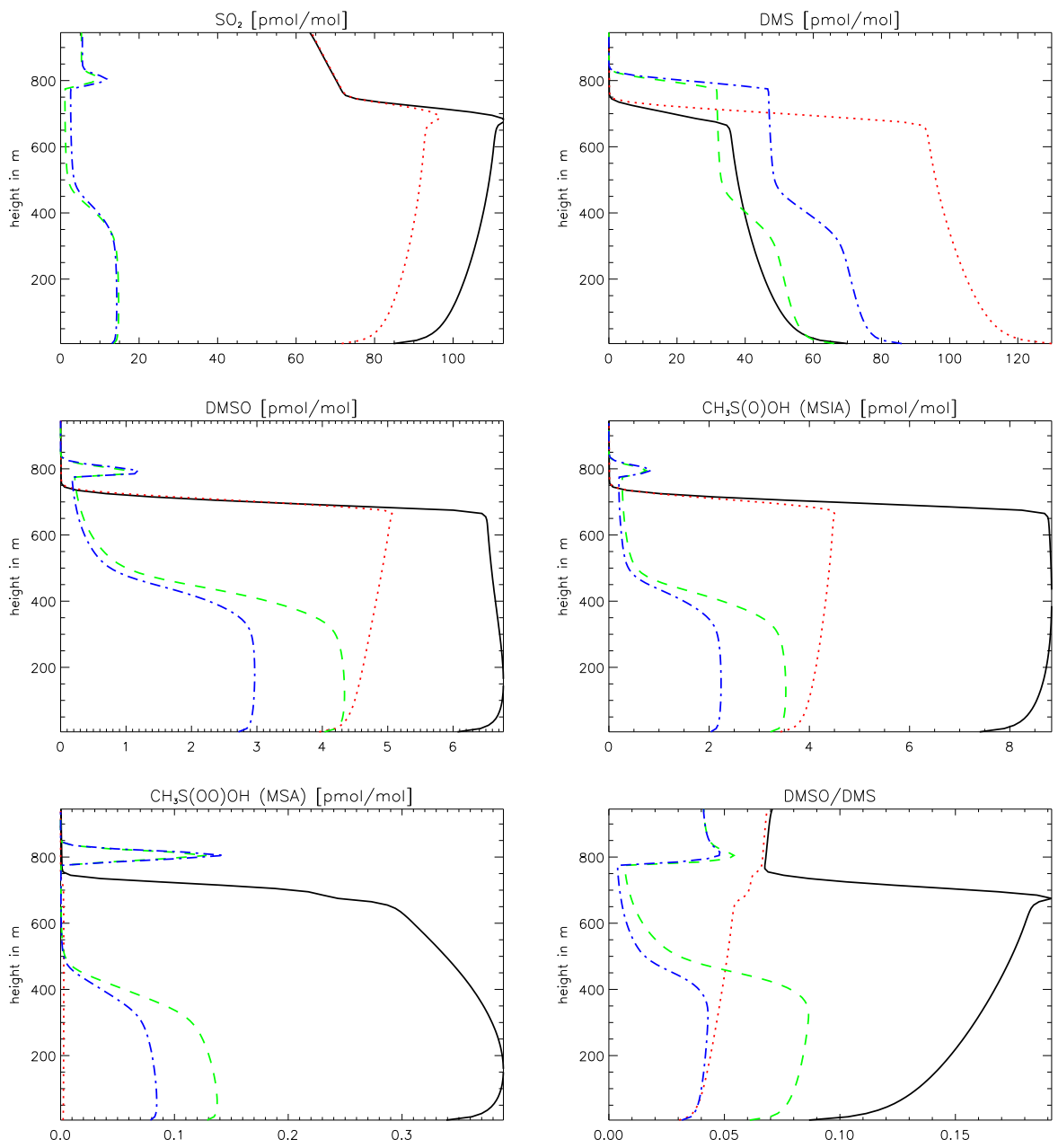

Fig. 6. Vertical profile of some sulfur species at noon on the second model day for the scenarios: "Kuk 5\%, cloud-free" (black, solid line), "Kuk 5\%, nh, cloud-free" (red, dotted line), "Kuk 5\%, cloudy" (green, dashed line), and "Kuk 5\%, nh, cloudy" (blue, dash-dotted line). Slow vertical exchange across the inversion that caps the MBL leads to the small peaks in the cloudy runs above the inversion where uptake on particles is small.

smaller in summer in halogen runs than in runs without halogens and $64 \%$ in winter. One has to keep in mind that due to strong uptake by the cloud droplets the gas phase concentrations of $\mathrm{SO}_{2}$ in the cloud runs is more than an order of magnitude smaller than in cloud-free runs. The importance of gas phase reactions for the formation of MSA in the cloudy runs is minimal, they never contribute more than $2 \%$ to the total MSA formation.

Due to the fast uptake by droplets of the intermediate products in the addition pathway the production of MSA is strongly increased in the runs with halogen chemistry because of the dominance of addition as loss for DMS in these cases.

\subsubsection{Conclusions}

Our model runs show that there is still significant uncertainty about the end products of the DMS addition pathway. Es- pecially the sensitivity in the product yield of the reaction $\mathrm{MSIA}+\mathrm{OH}$ makes it hard to come to final conclusions. If no MSA is formed in this reaction and if the reaction MSIA $+\mathrm{O}_{3}$ is slower than assumed by Lucas and Prinn (2002), then the gas phase production of MSA under cloud-free conditions is about $2 \%$ in summer and $10 \%$ in winter of the total MSA formation. Or, phrased differently, gas-phase production of MSA would be of minor importance compared to production in aerosols. If, however, the reaction MSIA+OH had a MSA yield of only $5 \%$ it could become the dominant MSA production pathway (for both halogen and no halogen conditions). Then the DMS-abstraction pathway would be only of minor importance for MSA production.

Under cloudy conditions the gas phase contributes only about 2\% to the total formation rate of MSA and is insignificant for winter runs. The sensitivities to the gas phase reactions of MSIA are very weak due to the uptake of the MSIA precursor DMSO and the uptake of MSIA itself. 
The aqueous phase reaction MSIA+OH is the main source for total MSA when gas phase production of MSA is unimportant. Field measurements indicate that there has to be at least some formation of gas phase MSA in the atmosphere which we could not satisfactorily reproduce in the model without assuming that MSA is produced in the addition pathway.

\subsection{Oxidation of DMS}

In this section we discuss the roles of $\mathrm{OH}, \mathrm{NO}_{3}, \mathrm{BrO}, \mathrm{Cl}$, and $\mathrm{O}_{3, \text { aq }}$ for the oxidation of DMS as well as changes in the DMS $\longrightarrow \mathrm{SO}_{2}$ conversion efficiency.

\subsubsection{Model runs for cloud-free MBL}

The DMS oxidation rates are the same in the scenarios "Luc", "Yin", and "Kuk" because differences between these runs only affect the products of DMS. Inclusion of halogens increases the DMS destruction by about $25 \%$ in summer and by $100 \%$ in winter. The contribution of $\mathrm{BrO}$ to the destruction of DMS (averaged over model days 2-5) is about $64 \%$ in the summer runs and about $84 \%$ for the winter runs. The relative importance increases with time even though $\mathrm{BrO}$ concentrations stay constant because the concentration of the next most important oxidant $\mathrm{OH}$ decreases with time due to decreasing $\mathrm{O}_{3}$ which gets photochemically destroyed, especially by halogens. Note that it is this combination of bromine-catalyzed $\mathrm{O}_{3}$ destruction leading to a smaller contribution by $\mathrm{OH}$ to the oxidation of DMS and the presence of $\mathrm{BrO}$ as oxidant for DMS that leads to the high relative importance of $\mathrm{BrO}$. The contribution of $\mathrm{BrO}$ to total DMS destruction on days 2 and 3 is about $56 \%$ which is already a very high number. The addition pathway dominates in halogen runs with about $76 \%$ compared to $44 \%$ in the runs without halogens ( $89 \%$ vs. $58 \%$ in winter).

In the runs without halogen chemistry about 5-6\% and $11.5 \%$ in summer and winter, respectively, of the total DMS destruction is by $\mathrm{NO}_{3}$, the rest by $\mathrm{OH}$. This number is strongly dependent on $\mathrm{NO}_{\mathrm{x}}$ mixing ratios which were about 2-3 and $13 \mathrm{pmol} \mathrm{mol}^{-1}$ for runs with and without halogen chemistry, respectively. For the winter runs the mixing ratios are about 3 and $20 \mathrm{pmol} \mathrm{mol}^{-1}$ for runs with and without halogen chemistry, respectively. $\mathrm{NO}_{3}$ is relatively more important under winter than summer conditions because of longer nights and roughly $70 \%$ smaller concentrations of $\mathrm{OH}$ in winter. This is caused by an adjustment of the solar elevation and temperature to winter conditions; we did not change the chemical initial conditions. In summer $\mathrm{NO}_{3}$ contributes about $1 \%$ to the total DMS oxidation rate in the halogen runs and $\mathrm{OH}$ and $\mathrm{Cl}$ about $27 \%$ and $8 \%$, respectively (see also the discussion of seasonal differences in von Glasow et al., 2002a). The source for $\mathrm{NO}_{\mathrm{x}}$ in the model is a prescribed flux of $10 \mathrm{pmol} \mathrm{mol}^{-1} \mathrm{day}^{-1}$ (see Sect. 3). Furthermore, the pho- tolysis of $\mathrm{NO}_{3}^{-}$in sea salt aerosol leads to an additional flux of $\mathrm{NO}_{2}$ to the gas phase of about $0.7 \mathrm{pmol} \mathrm{mol}^{-1}$ per day.

We do not expect the contribution of $\mathrm{BrO}$ to be this high over the remote oceans but discuss these cases to illustrate the chemistry. In the scenarios "tropics" and "Cape Grim" (see Sect. 4.2.3) we will discuss smaller influence of halogen chemistry. To our knowledge there have been only two measurements of $\mathrm{BrO}$ in the MBL reported in the literature so far: Leser et al. (2003) found about $0.7 \mathrm{pmol} \mathrm{mol}^{-1}$ in the North Atlantic whereas Saiz-Lopez et al. (2004) measured up to $6 \mathrm{pmol} \mathrm{mol}^{-1}$ at Mace Head, Ireland. The presence of $\mathrm{BrO}$ has also been inferred from differential optical absorption spectrometry (DOAS) measurements in open-ocean surface air at Hawaii (Pszenny et al., 2004). Due to the predicted vertical profile in sea salt aerosol acidity with a maximum near the inversion that caps the MBL (von Glasow and Sander, 2001), BrO mixing ratios show a vertical profile in the model with maxima at the top of the MBL (see also von Glasow et al., 2002a). Around noon, they are about $1.5 \mathrm{pmol} \mathrm{mol}^{-1}$ at the surface and $2.5 \mathrm{pmol} \mathrm{mol}^{-1}$ near the inversion that caps the MBL. The morning peaks are between 4.5 and $6.2 \mathrm{pmol} \mathrm{mol}^{-1}$. BrO is never smaller than $1.5 \mathrm{pmol} \mathrm{mol}^{-1}$ during day.

\subsubsection{Model runs for cloudy MBL}

In cloud runs $\mathrm{BrO}$ is relatively less important as oxidant for DMS than in cloud-free runs but it is still a major oxidant if halogen chemistry is considered in the model. The addition pathway dominates the oxidation of DMS in halogen runs with about $62 \%$ compared to $40 \%$ in the runs without halogens ( $80 \%$ vs. $40 \%$ in winter). The importance of $\mathrm{OH}$ as oxidant for DMS increased in the halogen runs to about 55\% and that of $\mathrm{Cl}$ decreased to $3 \%$.

Based on the measurements of Gershenzon et al. (2001), Boucher et al. (2003) included the aqueous phase oxidation of DMS by $\mathrm{O}_{3}$ in a global model of the sulfur cycle and found it to contribute about $6 \%$ to the overall destruction of DMS. In our cloud runs including halogen chemistry it contributes about $4 \%$ and in runs without halogen chemistry $7 \%$ of the total DMS oxidation in the MBL. Under winter conditions, however, the contribution is $6 \%$ and $18.6 \%$, with and without halogen chemistry, respectively. It is unimportant under cloud-free conditions. These numbers suggest that this reaction should be included in models of the sulfur cycle, especially when looking at high latitudes or winter conditions.

\subsubsection{Model runs for special environments}

The BrO mixing ratios for the "tropics" scenario are small with $0.3 \mathrm{pmol} \mathrm{mol}^{-1}$ around noon and peak values of about $1.5 \mathrm{pmol} \mathrm{mol}^{-1}$. Nevertheless, the relative contribution of $\mathrm{BrO}$ to DMS oxidation is very significant with almost $17 \%$.

In the "Cape Grim" scenarios with clouds, the BrO contribution is very strong for summer with $38 \%$ but only about 
$14 \%$ during winter. We did additional runs for the "Cape Grim, summer" scenario where we enhanced the sea salt alkalinity by increasing the bicarbonate $\left(\mathrm{HCO}_{3}^{-}\right)$concentrations in fresh sea salt aerosol. These studies are based on field observations (Sievering et al., 1999) that enrichment of $\mathrm{HCO}_{3}^{-}$could occur at the ocean's surface where sea salt aerosol is produced from bubble bursting. They refer to this as "biological alkalinity". In sea salt aerosol $\mathrm{HCO}_{3}^{-}$acts as a buffer via the equilibrium $\mathrm{CO}_{2}+\mathrm{H}_{2} \mathrm{O} \longleftrightarrow \mathrm{HCO}_{3}^{-}+\mathrm{H}^{+}$. It titrates most of the acidity in sea salt until the $\mathrm{HCO}_{3}^{-}$reservoir is used up and only then the particle $\mathrm{pH}$ drops. $\mathrm{HCO}_{3}^{-}$ is therefore of major importance for the regulation of the $\mathrm{pH}$ of sea salt aerosol. We tested a $100 \%$ (" $2 \times \mathrm{HCO}_{3}^{-}$" run), a $150 \%$ (" $2.5 \mathrm{x} \mathrm{HCO}_{3}^{-}$” run), and a $350 \%$ (" $4.5 \times \mathrm{HCO}_{3}^{-}$” run) increase in $\mathrm{HCO}_{3}^{-}$. In these cases $\mathrm{BrO}$ mixing ratios were even smaller than in the "tropics" cases: $0.1-0.2 \mathrm{pmol} \mathrm{mol}^{-1}$ in the " $2 \mathrm{x}^{-} \mathrm{HCO}_{3}^{-}$" run and less than $0.1 \mathrm{pmol} \mathrm{mol}^{-1}$ in the " $2.5 \mathrm{x} \mathrm{HCO}_{3}^{-}$" and " $4.5 \mathrm{x} \mathrm{HCO}_{3}^{-}$" runs. For comparison: in the "Cape Grim, summer" run the BrO mixing ratios are 0.5$1.5 \mathrm{pmol} \mathrm{mol}^{-1}$. The relative contribution of $\mathrm{BrO}$ to DMS is still significant although drastically reduced in the runs with increased alkalinity: about $38 \%$ in the "Cape Grim, summer"

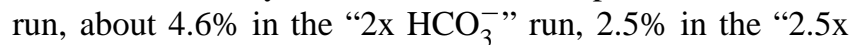
$\mathrm{HCO}_{3}^{-}$" run, and $1.3 \%$ in the " $4.5 \mathrm{x}^{-} \mathrm{HCO}_{3}^{-}$". The bromine deficit (calculated from the $\mathrm{Br}^{-}: \mathrm{Na}^{+}$ratio in the sea salt aerosol as compared to that in seawater) is with $13-33 \%$ in the "Cape Grim, summer" run smaller than the observed summer values of about 60-80\% (Ayers et al., 1999). The deficit is only $3.5 \%$ in the " $2 \mathrm{x} \mathrm{HCO}_{3}^{-}$" run and less than $1 \%$ in the " $2.5 \mathrm{x} \mathrm{HCO}_{3}^{-}$" and " $4.5 \mathrm{x} \mathrm{HCO}_{3}^{-}$" scenarios. This, however, and the very high seasalt $\mathrm{pH}$ values of 8-10 are unrealistic if compared with measurements that show $\mathrm{pH}$ values between 3.5 and 5.1 for clean to moderately polluted conditions (Keene and Savoie, 1998, 1999; Keene et al., 2002; Pszenny et al., 2004). Caused by this strong reduction of the activation of $\mathrm{Br}^{-}$, the development of gas phase chemistry in the scenarios with $\mathrm{HCO}_{3}^{-}$enrichment had a greater similarity with the non-halogen run than with the halogen run.

In the base cloud-free model run for "Cape Grim" conditions the $\mathrm{BrO}$ mixing ratio is with $5-15 \mathrm{pmol} \mathrm{mol}^{-1}$ unrealistically high, the bromine deficit of $30-85 \%$, however, is similar to the measured values of Ayers et al. (1999). The high gas phase values are due to high wind speeds leading to a high sea salt loading and efficient release of bromine from the aerosol to the gas phase as evident in the values for the bromine deficit. One way to explain the discrepency between model and field data would involve organic bromine compounds that "sequester" bromine (Toyota et al., 2003). In this study, however, we did not investigate this possibility. We also did runs with a $2.5 x$ and $4.5 x$ enrichment of $\mathrm{HCO}_{3}^{-}$and found the expected increase in sea salt aerosol $\mathrm{pH}$ and smaller $\mathrm{BrO}$ mixing ratios. On the other hand, the $\mathrm{Br}^{-}$deficits of 20 and $3 \%$ were again too small compared with measurements. The contribution of $\mathrm{BrO}$ to the DMS oxidation decreased from $78 \%$ in the run without increased sea salt alkalinity to $16 \%$ and $2.5 \%$ with a 2.5 and 4.5 fold enrichment in $\mathrm{HCO}_{3}^{-}$, respectively.

In the "Cape Grim, winter" scenarios the DMS flux from the ocean is reduced by more than a factor of twenty. BrO mixing ratios are less than $0.5 \mathrm{pmol} \mathrm{mol}^{-1}$ but it still plays an important role for the oxidation of DMS with $16 \%$ of the total. The most important oxidant is the $\mathrm{NO}_{3}$ radical with a contribution of $40 \%$ including halogen chemistry and $77 \%$ without it. $\mathrm{NO}_{\mathrm{x}}$ mixing ratios are $6-12 \mathrm{pmol} \mathrm{mol}^{-1}$ and the nighttime $\mathrm{NO}_{3}$ mixing ratios are up to $0.5 \mathrm{pmol} \mathrm{mol}^{-1}$. The main reason for the importance of $\mathrm{NO}_{3}$ are the small $\mathrm{OH}$ (see above) and $\mathrm{BrO}$ concentrations.

\subsubsection{DMS $\longrightarrow \mathrm{SO}_{2}$ conversion efficiency}

The DMS $\longrightarrow \mathrm{SO}_{2}$ conversion efficiency is a measure for the importance of gas phase reactions and for the production of new particle formation precursor gases. Many estimates of the DMS conversion efficiency have been published and cover a wide range roughly from 0.2 to 1 . Usually measurements of DMS, $\mathrm{SO}_{2}$ and sometimes $\mathrm{OH}$ are used together with photochemical models to derive the conversion efficiencies. As discussed in detail by de Bruyn et al. (2002), these calculations are very dependent on the reaction mechanism that was chosen and can even yield different results for the same field campaign. It is also not yet established if there is a latitude dependence of the conversion efficiency but measurements indicate that it is higher at low latitudes (see de Bruyn et al., 2002, and references therein).

The DMS $\longrightarrow \mathrm{SO}_{2}$ conversion efficiencies were calculated for all runs (see Tables 3 and 4), they range from 0.140 to 0.957 and showed an expected rise with increase in the rate constant of MSIA+OH. The conversion efficiency is reduced by only $2-3 \%$ if we use a yield of $5 \%$ for MSA in the "Kuk" scenario and by $4-7 \%$ for the "Kuk 10\%" run. It is strongly reduced under colder temperatures and with lower $\mathrm{OH}$ (see winter cases).

The $\mathrm{SO}_{2}$ yield from the oxidation of DMS is always smaller when halogen chemistry is included. This is caused by the higher DMS destruction rates in halogen runs and slower conversion of $\mathrm{CH}_{3} \mathrm{~S}$ to $\mathrm{CH}_{3} \mathrm{SO}_{2}$ that involves two reactions with $\mathrm{O}_{3}$ which gets depleted by halogen chemistry.

When halogen chemistry is accounted for, the destruction of DMS starts earlier in the morning and has a more abrupt onset (see Figs. 4 and 5) because of the early morning peak in BrO. This propagates into DMSO and $\mathrm{MSA}_{\mathrm{g}}$ (if the MSA yield in the reaction MSIA+OH is greater than zero) which also show a peak before noon. These diurnal variations might be used for a qualitative test during field campaigns to see if halogen chemistry was important. The diurnal variation of $\mathrm{BrO}$ will only show the morning and afternoon peaks as long as the $\mathrm{NO}_{\mathrm{x}}$ concentrations are not too high to make $\mathrm{NO}_{2}$ be the main sink (instead of $\mathrm{HO}_{2}$ ) for $\mathrm{BrO}$ (see also discussion in von Glasow et al., 2002a). 
In cloudy runs, the difference in the DMS $\rightarrow \mathrm{SO}_{2}$ conversion efficiency between runs with and without halogen chemistry is even higher than under cloud-free conditions and especially low under winter conditions because of the uptake of DMS and intermediate products like DMSO and MSIA by the cloud droplets.

\subsubsection{Conclusions}

We confirmed the influence of $\mathrm{BrO}$ in the oxidation of DMS. It strongly increases the importance of the addition branch in the oxidation of DMS even when present at mixing ratios smaller than $0.5 \mathrm{pmol} \mathrm{mol}^{-1}$. The general trend is that the inclusion of halogen chemistry leads to higher DMS oxidation rates and smaller DMS $\longrightarrow \mathrm{SO}_{2}$ conversion efficiencies. The DMS $\longrightarrow \mathrm{SO}_{2}$ conversion efficiency is also drastically reduced under cloudy conditions due to uptake of the intermediate products in the addition pathway. The presence of halogens changes the diurnal cycle sulfur species: the destruction of DMS starts earlier and the mixing ratios of the oxidation products (DMSO, MSIA, MSA, $\mathrm{SO}_{2}$, and $\mathrm{H}_{2} \mathrm{SO}_{4}$ ) peak earlier when halogen chemistry is included. We also confirmed the importance of the reaction $\mathrm{DMS}_{\mathrm{aq}}+\mathrm{O}_{3 \text {, aq }}$ for the oxidation of DMS under cloudy conditions, especially in winter.

\subsection{Sulfate vs. MSA and aerosol size}

Sulfur is present in the particles as $\mathrm{S}$ (IV) (sum of $\mathrm{SO}_{2}$, $\mathrm{HSO}_{3}^{-}, \mathrm{SO}_{3}^{2-}$, and MSA) and $\mathrm{S}(\mathrm{VI})$ (sum of $\mathrm{H}_{2} \mathrm{SO}_{4}, \mathrm{HSO}_{4}^{-}$, and $\mathrm{SO}_{4}^{2-}$ ). In many studies MSA is not included in the definition of $\mathrm{S}(\mathrm{IV})$; in the following we refer to the sum of $\mathrm{SO}_{2}$, $\mathrm{HSO}_{3}^{-}$, and $\mathrm{SO}_{3}^{2-}$ as $\mathrm{S}(\mathrm{IV})^{\star}$, which is a very small fraction of the particulate sulfur and is rapidly oxidized to $\mathrm{S}(\mathrm{VI})$. Seawater contains sulfate as well, which gets incorporated into sea salt aerosols. In order to distinguish between the additional sulfate that is taken up, usually the sea salt fraction of sulfate is subtracted in measurements (based on the constant ratios of sulfate and sodium in seawater) and this property is called non-sea-salt $\mathrm{SO}_{4}^{2-}\left(\right.$ nss- $\mathrm{SO}_{4}^{2-}$ ). We use this term nss$\mathrm{SO}_{4}^{2-}$ to refer to the sum of $\mathrm{H}_{2} \mathrm{SO}_{4}, \mathrm{HSO}_{4}^{-}$, and $\mathrm{SO}_{4}^{2-}$ not originating directly from the sea water. In the following sections we will discuss the production of particulate sulfur, and the MSA to nss- $\mathrm{SO}_{4}^{2-}$ ratio.

\subsubsection{Production of particulate sulfur}

In cloudy runs the conversion of the DMS-derived sulfur into particulate sulfur (MSA and nss- $\mathrm{SO}_{4}^{2-}$ ) is almost complete. In the cloud-free runs only $5-15 \%$ is taken up by particles, the rest remains in the gas phase mainly as $\mathrm{SO}_{2}$ and eventually gets deposited. The deposition rates of $\mathrm{SO}_{2}$ in the cloudfree runs are about ten times higher than in the cloudy runs.

Under cloud-free conditions the production of particulate sulfur is always higher when halogen chemistry is included.
In the "Luc" scenarios the difference is about $19 \%$ whereas it is $26 \%$ in the "Yin" and about $45-48 \%$ in the "Kuk" scenarios, respectively. In winter the differences increase to 65$94 \%$.

In the cloud-free runs $61-93 \%$ of the total MSA production occurs in the gas phase in summer and $70-88 \%$ in winter, respectively. If neither of the gas phase reactions MSIA $+\mathrm{O}_{3}$ (tested only for "Luc" scenarios) nor MSIA+OH are included then the contribution of the gas phase to total MSA production is reduced to about $2 \%$ in "Yin", $10 \%$ in "Yin, winter", and 5-6\% in "Kuk 0\%" (both with and without halogens). In the runs with a significant fraction of MSA formation in the gas phase ("Luc", "Kuk 5\%", and "tropics") the production of MSA is higher with halogen chemistry. A large fraction of the nss- $\mathrm{SO}_{4}^{2-}$ production takes place in the gas phase but it is less important in runs with halogen chemistry. The contribution by $\mathrm{HOX}(\mathrm{X}=\mathrm{Cl}, \mathrm{Br})$ in the sea salt aerosol is $42-51 \%$ in summer and $71-75 \%$ in winter, respectively, but it is only about $9 \%$ in the run for tropical conditions. Neglecting halogen chemistry reduces the production of nss- $\mathrm{SO}_{4}^{2-}$ in all cloud-free runs (except for the "tropics" scenarios were it remains about the same).

The oxidation of $\mathrm{S}(\mathrm{IV})^{\star}$ in aerosol particles by $\mathrm{O}_{3}$ is only important for high $\mathrm{pH}$ values. Due to the vertical decrease in seasalt aerosol $\mathrm{pH}$ (see von Glasow and Sander, 2001) this is the case only at the bottom of the MBL. Most of the sulfate production via this pathway occurs in the lowest 50$100 \mathrm{~m}$ and is rapidly deposited to the ocean. For the cloudfree model runs the contribution of $\mathrm{O}_{3 \text {, aq }}$ to the total nss$\mathrm{SO}_{4}^{2-}$ production rate is less than $2 \%$ in summer and about $7 \%$ in winter. For the runs without halogen chemistry, however, the relative contribution increased to $8-12 \%$ in summer and around $50 \%$ in winter. The contribution of $\mathrm{HOCl}_{\mathrm{aq}}$ and $\mathrm{HOBr}_{\mathrm{aq}}$ is about $42-54 \%$ in summer and up to $76 \%$ in winter. $\mathrm{H}_{2} \mathrm{O}_{2 \text {,aq }}$ is also an important oxidant in aerosols with $5-10 \%$ in halogen runs and 16-22\% in runs without halogen chemistry (but see the "Cape Grim" scenarios with increased alkalinity below).

In the runs with stratiform clouds the total nss- $\mathrm{SO}_{4}^{2-}$ production rate is higher for the runs without halogen chemistry. This can mainly be explained by greater concentrations of $\mathrm{S}(\mathrm{IV})^{\star}$ due to a greater importance of the DMS - abstraction pathway. Furthermore higher ozone concentrations in the gas phase lead to higher $\mathrm{OH}$ and $\mathrm{H}_{2} \mathrm{O}_{2}$ concentrations in both gas and aqueous phase and therefore greater importance of the reaction $\mathrm{H}_{2} \mathrm{O}_{2}$,aq $+\mathrm{S}(\mathrm{IV})$.

Under cloudy conditions $\mathrm{S}(\mathrm{IV})$ oxidation by $\mathrm{O}_{3, \text { aq }}$ is of minor importance due to low $\mathrm{pH}$ values of the order of 4-5. In summer it is less than $1.5 \%$ and in winter less than $4 \%$. As already discussed in von Glasow et al. (2002b) the oxidation of $\mathrm{S}(\mathrm{IV})$ by $\mathrm{HOCl}_{\mathrm{aq}}$ and $\mathrm{HOBr}_{\mathrm{aq}}$ contributes significantly to the total nss- $\mathrm{SO}_{4}^{2-}$ production rate with about $40 \%$. $\mathrm{H}_{2} \mathrm{O}_{2}$, aq is the most important oxidant with $50-55 \%$ in halogen and $86-91 \%$ in cloud free runs. The total production of 
particulate sulfur is higher if halogen chemistry is included because of the increase in MSA production in these cases. This is caused by the production of DMSO in the reaction DMS $+\mathrm{BrO}$ and consecutive uptake of DMSO to the particles and oxidation of it in the aqueous phase. More than $98 \%$ of the MSA is produced in the particles via MSIA $\mathrm{aq}+\mathrm{OH}_{\mathrm{aq}}$, mainly $(90-97 \%)$ in sulfate droplets.

The results were different for the "Cape Grim" scenarios. Due to higher windspeeds the flux of sea salt aerosols and therefore of alkalinity is greater than in the previously discussed process study runs and consequently the sea salt aerosol and sea salt cloud droplet $\mathrm{pH}$ values are higher. This is especially true for the " $2 \mathrm{x}^{-} \mathrm{HCO}_{3}^{-}$", " $2.5 \mathrm{x} \mathrm{HCO}_{3}^{-}$", and " $4.5 \times \mathrm{HCO}_{3}^{-}$" runs where we increased the bicarbonate content of each aerosol particle. The $\mathrm{pH}$ of sea water is about 8 but due to shrinking and loss of water the $\mathrm{pH}$ increases in sea salt aerosols near the surface to 9 in the "Cape Grim, summer" run and to 10 in the runs with increased sea salt alkalinity. In sea salt cloud droplets the $\mathrm{pH}$ is about 5-5.5 in the "Cape Grim, summer" run and up to 7.3 in the runs with enhanced $\mathrm{HCO}_{3}^{-}$. Therefore the $\mathrm{pH}$ of sea salt droplets but especially that of aerosols is high enough to make $\mathrm{O}_{3 \text {,aq }}$ an important oxidant.

In our cloudy model runs the total contribution of $\mathrm{O}_{3}$

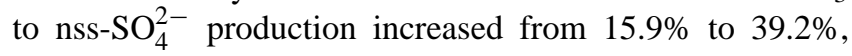
$45.5 \%$, and $51.9 \%$ in the runs "Cape Grim, summer", " $2 \mathrm{x}$ $\mathrm{HCO}_{3}^{-}$", " $2.5 \mathrm{x} \mathrm{HCO}_{3}^{-}$", and " $4.5 \mathrm{x} \mathrm{HCO}_{3}^{-}$" respectively. The total production rate of nss- $\mathrm{SO}_{4}^{2-}$, however, increased only insignificantly among the runs with different $\mathrm{HCO}_{3}^{-}$enrichment. This indicates that the oxidation of $\mathrm{S}(\mathrm{IV})^{\star}$ reached a saturation point and that merely redistribution among the different pathways occured. Virtually all nss- $\mathrm{SO}_{4}^{2-}$ production via $\mathrm{O}_{3 \text {,aq }}$ happened in sea salt particles. The partitioning between sea salt aerosol and droplets changes with increasing buffer capacity. In the "Cape Grim, summer" scenario $96 \%$ of the $\mathrm{O}_{3}$,aq related nss- $\mathrm{SO}_{4}^{2-}$ production is in sea salt aerosol and only $3.7 \%$ happened in sea salt droplets. The sea salt aerosol contribution to nss- $\mathrm{SO}_{4}^{2-}$ production by reaction with $\mathrm{O}_{3 \text {,aq }}$ decreases to $85 \%, 78.6 \%$, and $70.7 \%$ but the sea salt droplet contribution increases to $15.3 \%, 20.4 \%$, and $28.9 \%$ with increasing $\mathrm{HCO}_{3}^{-}$enrichment in the three cases with increased alkalinity. In all cloudy runs except for those with enrichment of $\mathrm{HCO}_{3}^{-}$the bulk of the nss- $\mathrm{SO}_{4}^{2-}$ formation happened in sulfate droplets. In the runs with $\mathrm{HCO}_{3}^{-}$ enrichment this is shifted to sea salt particles and leads to an increase in nss- $\mathrm{SO}_{4}^{2-}$ deposition of $55 \%$ in the " $2 \mathrm{x} \mathrm{HCO}_{3}^{-}$" run and $70 \%$ in the runs with higher $\mathrm{HCO}_{3}^{-}$enrichment. This is caused by the shorter lifetime of relatively large sea salt particles compared to the longer-lived sulfate particles (remember that we simulate only non-precipitating clouds).

Even though the gas phase halogen chemistry lost significantly in importance due to $\mathrm{HCO}_{3}^{-}$enrichment, the nss- $\mathrm{SO}_{4}^{2-}$ production by $\mathrm{HOCl}$ and $\mathrm{HOBr}$ still played an important role with $40.9 \%, 22.9 \%, 21.3 \%$, and $17.9 \%$ of the total in the runs without $\mathrm{HCO}_{3}^{-}$enrichment, with $2 \mathrm{x}, 2.5 \mathrm{x}$, and $4.5 \mathrm{x} \mathrm{HCO}_{3}^{-}$ enrichment, respectively.

Reduced DMS emissions result in a strong decrease in the production of particulate sulfur in the "Cape Grim, winter" runs. Due to the absence of significant sources of acidity in winter the $\mathrm{Br}^{-}$deficit is similar to observations with a maximum of $7 \%$ leading to the already mentioned small $\mathrm{BrO}$ mixing ratios. But again even small concentrations of $\mathrm{HOCl}$ and $\mathrm{HOBr}$ in the droplets lead to a contribution of $22 \%$ of these species to total nss- $\mathrm{SO}_{4}^{2-}$ production.

In the cloud-free "Cape Grim, summer" run the nss- $\mathrm{SO}_{4}^{2-}$ production rate increases from $23.3 \mathrm{~mol} \mathrm{~m}^{-3} \mathrm{~d}^{-1}$ in the run without enrichment of alkalinity to $31.7 \mathrm{~mol} \mathrm{~m}^{-3} \mathrm{~d}^{-1}$ in the " $2.5 \mathrm{x} \mathrm{HCO}_{3}^{-}$" run but it decreases again to $30.9 \mathrm{~mol} \mathrm{~m}^{-3} \mathrm{~d}^{-1}$ in the " $4.5 \times \mathrm{HCO}_{3}^{-}$" run. This is due to a reduction in the oxidation of DMS caused by less $\mathrm{BrO}$ and therefore less precursors for particulate sulfur. The fraction of oxidized DMS that ends up in particles, however, increases from $39 \%$ to $62 \%$ and $64 \%$ in the three runs it therefore does not show the saturation effect that we observed in the cloudy "Cape Grim" runs. This fraction is also significantly higher than in the other cloud-free runs that we discussed. The deposition of sulfate increased by $61 \%$ and $72 \%$ in the runs with $2.5 \times$ and $4.5 \times$ more $\mathrm{HCO}_{3}^{-}$, respectively, compared to the base "Cape Grim" run.

The aqueous phase reaction of MSA with $\mathrm{OH}$ (forming sulfate) is unimportant both as sink for MSA and as source of nss- $\mathrm{SO}_{4}^{2-}$ in cloud-free runs except for the "tropics" scenario where it accounts for $0.2 \%$ and $4.4 \%$ of the total nss$\mathrm{SO}_{4}^{2-}$ production with and without halogens, respectively. In cloudy runs, however, it contributes about $8-10 \%$ in nohalogen runs and $11-15 \%$ in halogen runs to the total oxidation rate but in our "Cape Grim, winter" scenarios the contribution is $27 \%$ and $10 \%$, for runs with and without halogen chemistry, respectively. These rates indicate that the reaction $\mathrm{MSA}_{\mathrm{aq}}+\mathrm{OH}$ is a major contributor to nss- $\mathrm{SO}_{4}^{2-}$ production in the cloudy MBL. In our "Cape Grim, summer" cases it contributed only $2-3 \%$.

\subsubsection{MSA:nss-SO ${ }_{4}^{2-}$}

In field campaigns often the ratio of MSA to nss- $\mathrm{SO}_{4}^{2-}$ is measured in aerosol particles. The MSA to nss- $\mathrm{SO}_{4}^{2-}$ ratio is dependent not only on processes occuring during a certain time period that is being studied but also on the particle history. In the field these effects cannot be separated but in a model they can. In the model we initialized our sulfate aerosol without MSA and therefore have small absolute MSA to nss- $\mathrm{SO}_{4}^{2-}$ ratios even after strong uptake of MSA. To avoid this problem we discuss the ratios of the production of MSA to the production of $n s s-\mathrm{SO}_{4}^{2-}, \mathrm{P}(\mathrm{MSA}): \mathrm{P}\left(\mathrm{nss}-\mathrm{SO}_{4}^{2-}\right)$, using the rates of MSA and nss- $\mathrm{SO}_{4}^{2-}$ production within the particles including uptake from the gas phase. Especially in the 
sulfate particles this changes the ratios drastically. To illustrate this we list two examples from the "Kuk 5\%" scenarios for sulfate aerosol: cloud-free MSA:nss$\mathrm{SO}_{4}^{2-}=0.013, \quad \mathrm{P}(\mathrm{MSA}): \mathrm{P}\left(\mathrm{nss}-\mathrm{SO}_{4}^{2-}\right)=0.331 ; \quad$ cloudy: MSA:nss-SO ${ }_{4}^{2-}=0.089, \mathrm{P}(\mathrm{MSA}): \mathrm{P}\left(\mathrm{nss}-\mathrm{SO}_{4}^{2-}\right)=0.472$.

The $\mathrm{P}(\mathrm{MSA})$ to $\mathrm{P}\left(\mathrm{nss}-\mathrm{SO}_{4}^{2-}\right)$ ratios are only then the same quantities as measured in the field when the ocean was the only source for sulfur and when no significant collisioncoalescence of particles with different origin occured. If part of the aerosol population has been advected from the continent with pollution source for sulfate, the MSA to nss- $\mathrm{SO}_{4}^{2-}$ ratio is smaller. Therefore one might expect that the modeled ratios are higher than the measured ones except for very clean regions without any advection of pollution. Values for $\mathrm{P}(\mathrm{MSA}): \mathrm{P}\left(\mathrm{nss}-\mathrm{SO}_{4}^{2-}\right)$ are listed in Table 5.

Measured MSA to nss-SO $\mathrm{S}_{4}^{2-}$ ratios span a wide range depending on the importance of pollution, which decreases the value, and latitude: generally higher values are measured at higher latitudes. Reported values of MSA:nss- $\mathrm{SO}_{4}^{2-}$ are between 0.002 (Kouvarakis and Mihalopoulos, 2002) and 0.44 (Sciare et al., 2001).

In the model runs most of the nss- $\mathrm{SO}_{4}^{2-}$ and MSA are in the sulfate particles which is qualitatively confirmed by Saltzman et al. (1986) who found that most of these species can be found in small particles.

The $\mathrm{P}(\mathrm{MSA})$ to $\mathrm{P}\left(\mathrm{nss}-\mathrm{SO}_{4}^{2-}\right)$ ratio is reduced in sea salt particles in all cloud-free runs when halogen chemistry is included, indicating that in these cases the increase in MSA production is less important than increase due to production of nss- $\mathrm{SO}_{4}^{2-}$ in the particles.

For the sulfate aerosols in the cloud-free runs the ratios are very similar in halogen and no-halogen runs for the "Yin" and the "Kuk 0\%" scenarios but the ratio is higher in the halogen runs for the other scenarios. This is caused by the high fraction of MSA being produced in the aerosols of about $33 \%$ and $45 \%$ in "Yin" and the "Kuk 0\%", respectively and very little uptake of MSA from the gas phase.

Neglecting halogen chemistry reduces the $\mathrm{P}(\mathrm{MSA})$ to $\mathrm{P}\left(\mathrm{nss}-\mathrm{SO}_{4}^{2-}\right)$ ratio in the droplets under cloudy conditions, indicating that in these cases the increase in MSA production is more important than increase due to production of nss- $\mathrm{SO}_{4}^{2-}$ in the particles.

\subsubsection{Seasonal variation of MSA:nss- $\mathrm{SO}_{4}^{2-}$ at Cape Grim}

For temperatures approximately below $8^{\circ} \mathrm{C}$ the addition reaction of $\mathrm{OH}$ with DMS becomes faster than abstraction. This implies higher yields of MSIA which is either taken up by particles and reacts to MSA or reacts in the gas phase to MSA and/or produces $\mathrm{CH}_{3} \mathrm{SO}_{2}$ which reacts to $\mathrm{CH}_{3} \mathrm{SO}_{3}$. Under cold conditions the formation of MSA from $\mathrm{CH}_{3} \mathrm{SO}_{3}$ is more important so the general expectation is that MSA:nss- $\mathrm{SO}_{4}^{2-}$ is higher in winter than in summer.
The field data of Ayers et al. (1991) and Andreae et al. (1999) from Cape Grim, Tasmania, show higher DMS, particulate MSA, and nss- $\mathrm{SO}_{4}^{2-}$ in summer than in winter but also a peak of the MSA to nss- $\mathrm{SO}_{4}^{2-}$ ratio in summer. This implies that other processes than just the previously mentioned temperature dependence must play a role or that the assumption of MSA production only from the reaction $\mathrm{CH}_{3} \mathrm{SO}_{3}+\mathrm{HO}_{2}$ (see e.g. Yin et al. (1990) mechanism) is wrong.

Ayers et al. (1996) compared field data with a photochemical model that uses a chemical mechanism which is mainly based on Yin et al. (1990), assuming that MSA is only formed in the abstraction pathway. To fit their model to data observed at Cape Grim, however, they have to assume a very high rate coefficient for the thermal decomposition of $\mathrm{CH}_{3} \mathrm{SO}_{3}\left(\mathrm{k}=1.1 \times 10^{17} \exp (-12057 / T)\right)$.

Andreae et al. (1999) proposed that $\mathrm{SO}_{2}$ sources other than the oxidation of DMS play a role in the seasonal variation of MSA:nss- $\mathrm{SO}_{4}^{2-}$. Another possibility is to assume that MSA formation is also occuring in the addition pathway. Koga and Tanaka (1996) assume that MSA is predominantly produced in the addition pathway via assumed reactions of the DMS-OH adduct. They pointed to the importance of the $\mathrm{DMS}+\mathrm{NO}_{3}$ reaction that according to their box-model runs explained the difference between winter and summer. In their model the reaction DMS $+\mathrm{NO}_{3}$ is the main sink for $\mathrm{NO}_{3}$ and a smaller ocean-flux of DMS in winter implies a smaller sink for $\mathrm{NO}_{3}$. This results in $\mathrm{NO}_{3}$ concentrations that are a factor of 4-5 higher in winter than in summer. They calculate a reduction in $\mathrm{OH}$ concentrations of a factor of 8 from summer to winter. The net result is a decrease in MSA:nss- $\mathrm{SO}_{4}^{2-}$ in winter compared to summer.

A greater importance of halogens in summer than in winter would be an additional explanation for higher MSA:nss$\mathrm{SO}_{4}^{2-}$ in summer than in winter if clouds are present and/or if MSA is produced in the gas phase from MSIA (see numbers in Table 5). This idea is supported by the measurements of Ayers et al. (1999) who showed that at Cape Grim, the loss of bromine from sea salt aerosol was strongest in summer.

\subsubsection{Conclusions}

In cloud-free model runs between 5 and $15 \%$ of the oxidized DMS reacts further to particulate sulfur, in cloudy runs this fraction is almost $100 \%$. In general more particulate sulfur is formed when halogen chemistry is included. If $\mathrm{HCO}_{3}^{-}$enrichment is prescribed in sea salt aerosol the sea salt aerosol and cloud droplet $\mathrm{pH}$ values are high enough to make the reaction of $\mathrm{S}(\mathrm{IV})^{\star}$ with $\mathrm{O}_{3}$ dominant. It leads to a shift from MSA to nss- $\mathrm{SO}_{4}^{2-}$ production but increases the total nss- $\mathrm{SO}_{4}^{2-}$ only slightly because almost all available sulfur is already oxidized to particulate sulfur in the base scenario. It would also increase sulfate deposition by $55-70 \%$. High enrichments of $\mathrm{HCO}_{3}^{-}$in fresh sea salt lead to bromide deficits in the aerosol that are too small and sea salt aerosol $\mathrm{pH}$ values 
that are too high compared to measurements, so that additional acidity sources would have to be active if these enrichments were widespread over the oceans. Without increased alkalinity the gas phase mixing ratios of $\mathrm{BrO}$ are too high which could be due to neglecting reactions with organic compounds that can sequester bromine.

Including halogen chemistry leads to greater formation rates of particulate sulfur under most conditions. $\mathrm{HOCl}$ and $\mathrm{HOBr}$ are important for the oxidation of $\mathrm{S}(\mathrm{IV})^{\star}$ in particles even when the gas phase halogen concentrations and bromide release from the sea salt aerosol are small.

We found the reaction $\mathrm{MSA}_{\mathrm{aq}}+\mathrm{OH}_{\mathrm{aq}}$ to contribute about $10-15 \%$ to the production of nss- $\mathrm{SO}_{4}^{2-}$ in clouds. It is unimportant for cloud-free model runs.

An additional explanation for the higher MSA:nss- $\mathrm{SO}_{4}^{2-}$ ratio in aerosols at Cape Grim in summer than winter (contrary to what is expected from the temperature dependence of the involved reactions) might be the greater influence of halogens in summer in the production of MSA.

\subsection{Diurnal variation of $\mathrm{Br}^{-}$}

Our "generic" cloud-free model runs (e.g. "Kuk, 5\%") have a small $\mathrm{Br}^{-}$to $\mathrm{Na}^{+}$ratio in the sea salt aerosol or in other words a very high bromine deficit, implying that most of the bromine is in the gas phase. Then the diurnal variation of sea salt $\mathrm{Br}^{-}$is mainly determined by exchange processes between particulate phases and the gas phase and $\mathrm{Br}^{-}$shows a peak during day and a minimum during night (see also von Glasow et al., 2002a). Under conditions when the multiphase catalytic cycles are not as efficient as in the base scenario due to lower gas phase acidity, lower gas phase $\mathrm{O}_{3}$, and/or higher temperature, then the additional bromide from the emission of fresh sea salt is not as rapidly released and accumulates over night in the sea salt aerosol and is depleted during day. This leads to a reversed diurnal variation in sea salt aerosol $\mathrm{Br}^{-}$and bromide deficit as is the case in the "tropics" and "Cape Grim" scenarios. Figure 7 shows the $\mathrm{Br}^{-}$loss for the "Kuk, 5\%" and the "tropics" scenarios.

This is in accordance with field studies (Rancher and Kritz, 1980; Sander et al., 2003; Pszenny et al., 2004) that found under conditions with bromine deficits of less than $90 \%$ that sea salt $\mathrm{Br}^{-}$has a maximum in the early morning and is being depleted during the day.

In von Glasow et al. (2002b) we showed that the presence of a stratiform cloud also changes the diurnal variation of the $\mathrm{Br}^{-}$concentration and brings it into accordance with measurements.

\section{Final conclusions and climate relevance}

We show that halogens play an important role in the cycle of sulfur in the atmosphere. BrO increases the oxidation rate of DMS even if it is present in small concentrations and $\mathrm{HOCl}$

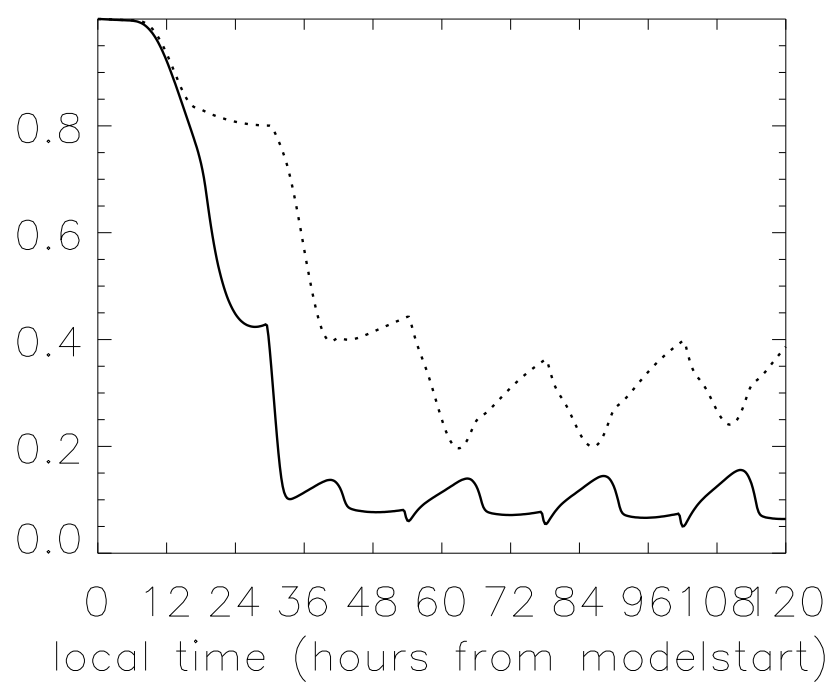

Fig. 7. Temporal evolution of the bromide loss in $50 \mathrm{~m}$ altitude in the sea salt aerosol for the cloud-free scenarios "kuk, 5\%" (solid line) and "tropics" (dashed line). Shown is the ratio of $\mathrm{Br}^{-}: \mathrm{Na}^{+}$in sea salt aerosol compared to the same ratio in sea water (enrichment factor).

and $\mathrm{HOBr}$ increase the oxidation of S(IV) ${ }^{\star}$ even if gas phase halogen concentrations are very small (below the detection limit of current instruments). In most cases the presence of halogens leads to an increase of the production rate of particulate sulfur.

Under cloud-free conditions the products of the reaction $\mathrm{MSIA}+\mathrm{OH}$ are important to estimate the final products of DMS addition. If MSA is formed in this reaction - even with a very small yield of $5 \%$ - then most MSA is being formed in the gas phase, if the yield if $0 \%$, then most of the MSA is formed in the aerosol phase. If no MSA is formed in the gas phase then more $\mathrm{SO}_{2}$, a precursor for new particle formation, is formed through the addition pathway. Here, important uncertainties still exist.

Under cloudy conditions the uptake of DMSO and MSIA to droplets results in a contribution of the gas phase to the total formation rate of MSA of only about $2 \%$. The aqueous phase reaction MSIA+OH is the main source for total MSA when gas phase production of MSA is unimportant. In clouds especially during winter the aqueous phase reaction DMS $+\mathrm{O}_{3}$ contributes $4-18 \%$ to total DMS oxidation.

The reaction $\mathrm{MSA}_{\mathrm{aq}}+\mathrm{OH}$ contributes about $10 \%$ to the production of nss- $\mathrm{SO}_{4}^{2-}$ in clouds. It is unimportant for cloud-free model runs. Sulfate production by $\mathrm{HOCl}_{\mathrm{aq}}$ and $\mathrm{HOBr}_{\mathrm{aq}}$ is important in cloud droplets even for small $\mathrm{Br}^{-}$ deficits and related small gas phase halogen concentrations.

We want to propose the following topics for future research to further our understanding of this fascinating and important field: i) the exact product yield of the gas phase reaction $\mathrm{MSIA}+\mathrm{OH}$, ii) the relative importance of the addition and the abstraction pathway in the oxidation of DMS, 
e.g. by measuring DMSO and MSIA in the gas phase, iii) the source of gas phase MSA under different conditions, iv) the diurnal variation of DMS, DMSO, MSIA which might be helpful to check if $\mathrm{BrO}$ was relevant as oxidant for DMS, v) more measurements of sea salt aerosol $\mathrm{pH}$ to test if $\mathrm{HCO}_{3}^{-}$ enrichment might be a widespread phenomena and to find out where acidity-induced halogen activation is occuring.

Potential anthropogenic impacts on the DMS cycle that should be considered in future studies as well are first a possible increase in $\mathrm{OH}$ concentrations over the Southern Ocean. This is caused by the decrease of the stratospheric ozone layer due to the anthropogenically released CFC gases resulting in increased ultraviolett radiation, especially in spring and summer in high southern latitudes. Furthermore industrial emissions of inorganic bromine could contribute to tropospheric bromine and therefore increase the effects discussed in this paper.

So far we mentioned only the effects of chemical reactions on the production of particulate sulfur and the precursors of new particle formation that lead to less but bigger aerosol particles. These effects combined would lead to a reduction of cloud albedo, which is often refered to as "first indirect aerosol effect". Fewer and bigger aerosol particles also lead to another effect: a more efficient initiation of collision-coalescence processes among droplets which is the main precipitation formation mechanism in warm (i.e. icefree) clouds. This would cause an increase of the wash-out of particles and reduce cloud lifetime thereby even further reducing the cloud aldedo. The cloud lifetime effect is often refered to as "second indirect effect".

Note that all these chemistry - cloud links lead to a reduction of cloud albedo as opposed to the anthropogenic indirect aerosol effect which results in an increase in cloud albedo (e.g. Intergovernmental Panel on Climate Change, 2001).

Acknowledgements. We want to thank I. Barnes, A. Kukui, G. Le Bras, J. Cainey, H. Sievering, R. Sander, and D. Rosenfeld for helpful discussions and making their work available to us before publication.

Edited by: G. Ayers

\section{References}

Allen, H. C., Gragson, D. E., and Richmond, G. L.: Molecular structure and adsorption of dimethyl sulfoxide at the surface of aqueous solutions, J. Phys. Chem. B, 103, 660-666, 1999.

Andreae, M. O., Elbert, W., Cai, Y., Andreae, T. W., and Gras, J.: Non-sea-salt sulfate, methanesulfonate, and nitrate aerosol concentrations and size distributions at Cape Grim, Tasmania, J. Geophys. Res., 104, 21 695-21 706, 1999.

Arsene, C., Barnes, I., Becker, K. H., Schneider, W. F., Wallington, T. T., Mihalopoulos, N., and Patroescu-Klotz, I. V.: Formation of methane sulfinic acid in the gas-phase $\mathrm{OH}$-radical initiated oxidation of dimethyl sulfoxide, Environ. Sci. Technol., 36, 5155$5163,2002$.
Atlas, E., Pollock, W., Greenberg, J., Heidt, L., and Thompson, A. M.: Alkyl nitrates, nonmethane hydrocarbons, and halocarbon gases over the equatorial Pacific-ocean during SAGA-3, J. Geophys. Res., 98, 16933-16947, 1993.

Ayers, G. P., Ivey, J. P., and Gillett, R. W.: Coherence between seasonal cycles of dimethylsulphide during a phytoplankton bloom, Nature, 349, 404-406, 1991.

Ayers, G. P., Bartley, S. T., Ivey, J. P., and Forgan, B. W.: Dimethylsulfide in marine air at Cape Grim, $41^{\circ} \mathrm{S}$, J. Geophys. Res., 100, $21013-21021,1995$.

Ayers, G. P., Cainey, J. M., Granek, H., and Leck, C.: Dimethylsulfide oxidation and the ratio of methanesulfonate to non seasalt sulfate in the marine aerosol, J. Atmos. Chem., 25, 307-325, 1996.

Ayers, G. P., Cainey, J. M., Gillett, R. W., Saltzman, E. S., and Hooper, M.: Sulfur dioxide and dimethyl sulfide in marine air at Cape Grim, Tasmania, Tellus, 49B, 292-299, 1997a.

Ayers, G. P., Granek, H., and Boers, R.: Ozone in the marine boundary layer at Cape Grim: Model simulation, J. Atmos. Chem., 27, 179-195, 1997b.

Ayers, G. P., Gillett, R. W., Cainey, J. M., and Dick, A. L.: Chloride and bromide loss from sea-salt particles in Southern Ocean air, J. Atmos. Chem., 33, 299-319, 1999.

Bardouki, H., Berresheim, H., Vrekoussis, M., Sciare, J., Kouvarakis, G., Oikonomou, K., Schneider, J., and Mihalopoulos, N.: Gaseous (DMS, MSA, $\mathrm{SO}_{2}, \mathrm{H}_{2} \mathrm{SO}_{4}$ and DMSO) and particulate (sulfate and methanesulfonate) sulfur species over the northeastern coast of Crete, Atmos. Chem. Phys., 3, 1871-1886, 2003.

Barnes, I., Bastian, V., Becker, K. H., and Overath, R. D.: Kinetic studies of the reactions of $\mathrm{IO}, \mathrm{BrO}$ and $\mathrm{ClO}$ with DMS, Int. J. Chem. Kinet., 23, 579-591, 1991.

Barry, R. G. and Chorley, R. J.: Atmosphere, Weather \& Climate, Routledge, 1998.

Bedjanian, Y., Poulet, G., and Bras, G. L.: Kinetic study of the reaction of $\mathrm{BrO}$ radicals with dimethylsulfide, Int. J. Chem. Kinet., 28, 383-389, 1996.

Boucher, O., Moulin, C., Belviso, S., Aumont, O., Bopp, L., Cosme, E., von Kuhlmann, R., Lawrence, M. G., Pham, M., Redyy, M. S., Sciare, J., and Venkataraman, C.: Sensitivity study of dimethylsulphide (DMS) atmospheric concentrations and sulphate aerosol indirect radiative forcing to the DMS source representation and oxidation, Atmos. Chem. Phys., 3, 49-65, 2003.

Charlson, R. J., Lovelock, J. E., Andreae, M. O., and Warren, S. G.: Oceanic phytoplankton, atmospheric sulphur, cloud albedo and climate, Nature, 326, 655-661, 1987.

Chuck, A. L., Turner, S. M., and Liss, P. S.: Direct evidence for a marine source of $C_{1}$ and $C_{2}$ alkyl nitrates, Science, 297, 11511154, 2002.

Davis, D., Chen, G., Bandy, A., Thornton, D., Eisele, F., Mauldin, L., Tanner, D., Lenschow, D., Fuelberg, H., Huebert, B., Heath, J., Clarke, A., and Blake, D.: Dimethyl sulfide oxidation in the equatorial Pacific: Comparison of model simulations with field observations for DMS, $\mathrm{SO}_{2}, \mathrm{H}_{2} \mathrm{SO}_{4}(\mathrm{~g}), \mathrm{MSA}(\mathrm{g})$, MS, and nss, J. Geophys. Res., 104, 5765-5784, 1999.

De Bruyn, W. J., Shorter, J. A., Davidovits, P., Worsnop, D. R., Zahniser, M. S., and Kolb, C. E.: Uptake of gas phase sulfur species methanesulfonic acid, dimethylsulfoxide, and dimethyl sulfone by aqueous surface, J. Geophys. Res., 99, 16 927-16932, 
1994.

de Bruyn, W. J., Harvey, M.,, Cainey, J. M., and Saltzman, E. S.: DMS and $\mathrm{SO}_{2}$ at Baring Head, New Zealand: Implications for the yield of $\mathrm{SO}_{2}$ from DMS, J. Atmos. Chem., 41, 189-209, 2002.

Falbe-Hansen, H. S. S., Jensen, N. R., Pedersen, T., and Hjorth, J.: Atmospheric gas-phase reactions of dimethylsulphoxide and dimethylsulphone with $\mathrm{OH}$ and $\mathrm{NO}_{3}$ radicals, $\mathrm{Cl}$ atoms and ozone, Atmos. Environ., 34, 1543-1551, 2000.

Gershenzon, M., Davidovits, P., Jayne, J. T., Kolb, C. E., and Worsnop, D. R.: Simultaneous uptake of DMS and ozone on water, J. Phys. Chem. A, 105, 7031-7036, 2001.

Hoppel, W. A. and Frick, G. M.: Submicron aerosol size distributions measured over the tropical and south Pacific, Atmos. Environ., 24A, 645-659, 1990.

Ingham, T., Bauer, D., Sander, R., Crutzen, P. J., and Crowley, J. N.: Kinetics and products of the reactions $\mathrm{BrO}+\mathrm{DMS}$ and $\mathrm{Br}+\mathrm{DMS}$ at 298 k, J. Phys. Chem. A, 103, 7199-7209, 1999.

Intergovernmental Panel on Climate Change: Climate Change 2001 - The Scientific Basis, Cambridge University Press, 2001.

Jefferson, A., Tanner, D. J., Eisele, F. L., Davis, D. D., Chen, G., Crawford, J., Huey, J. W., Torres, A. L., and Berresheim, H.: $\mathrm{OH}$ photochemistry and methane sulfonic acid formation in the coastal Antarctic boundary layer, J. Geophys. Res., 103, 16471656, 1998.

Keene, W. C. and Savoie, D. L.: The pH of deliquesced sea-salt aerosol in polluted marine air, Geophys. Res. Lett., 25, 21812184, 1998.

Keene, W. C. and Savoie, D. L.: Correction to "The $\mathrm{pH}$ of deliquesced sea-salt aerosol in polluted marine air", Geophys. Res. Lett., 26, 1315-1316, 1999.

Keene, W. C., Pszenny, A. A. P., Maben, J. R., and Sander, R.: Variation of marine aerosol acidity with particle size, Geophys. Res. Lett., 29, doi: 10.1029/2001GL013 881, 2002.

Koga, S. and Tanaka, H.: Simulation of seasonal variations of sulfur compounds in the remote marine atmosphere, J. Atmos. Chem., 23, 163-192, 1996.

Kouvarakis, G. and Mihalopoulos, N.: Seasonal variation of dimethylsulfide in the gas phase and of methanesulfonate and non-sea-salt sulfate in the aerosols phase in the eastern Mediterranean atmosphere, Atmos. Environ., 36, 929-938, 2002.

Kukui, A., Borissenko, D., Laverdet, G., and Bras, G. L.: Gas phase reactions of $\mathrm{OH}$ radicals with dimethyl sulfoxide and methane sulfonic acid using turbulent flow reactor and chemical ionization mass spectrometry, J. Phys. Chem. A, 107, 5732-5742, 2003.

Lelieveld, J., Crutzen, P. J., and Rodhe, H.: Zonal average cloud characteristics for global atmospheric chemistry modelling, Tech. Rep. CM-76, Dep. of Meteorology, University of Stockholm (MISU), 1989.

Leser, H., Hönninger, G., and Platt, U.: MAX-DOAS measurements of $\mathrm{BrO}$ and $\mathrm{NO}_{2}$ in the marine boundary layer, Geophys. Res. Lett., 30, 1537, doi:10.1029/2002GL015 811, 2003.

Lucas, D. D. and Prinn, R. G.: Mechanistic studies of dimethylsulfide oxidation products using an observationally constrained model, J. Geophys. Res., 107, doi: 10.1029/2001JD000 843, 2002.

Mauldin, R. L., Eisele, F. L., Tanner, D. J., Kosciuch, E., Shetter, R., Lefer, B., Hall, S. R., Nowak, J. B., Buhr, M., Chen, G., Wang, P., and Davis, D.: Measurements of $\mathrm{OH}, \mathrm{H}_{2} \mathrm{SO}_{4}$, and MSA at the
South Pole during ISCAT, Geophys. Res. Lett., 28, 3629-3632, 2001.

McFiggans, G., Plane, J. M. C., Allan, B. J., Carpenter, L. J., Coe, H., and O'Dowd, C.: A modellig study of iodine chemistry in the marine boundary layer, J. Geophys. Res., 105, 14371-14377, 2000.

Monks, P. S., Carpenter, L. J., Penkett, S. A., Ayers, G. P., Gillet, R. W., Galbally, I. E., and Meyer, C. P.: Fundamental ozone photochemistry in the remote marine boundary layer: The SOAPEX experiment, measurements and theory, Atmos. Environ., 32, 3647-3664, 1998.

Monks, P. S., Salisbury, G., Holland, G., Penkett, S. A., and Ayer, G. P.: A seasonal comparison of ozone photochemistry in the remote marine boundary layer, Atmos. Environ., 34, 2547-2561, 2000.

Nakano, Y., Goto, M., Hashimoto, S., Kawasaki, M., and Wallington, T. J.: Cavity ring-down spectroscopic study of the reactions of $\mathrm{Br}$ atoms and $\mathrm{BrO}$ radicals with dimethyl sulfide, J. Phys. Chem. A, 105, 11 045-11 050, 2001.

Nakano, Y., Enami, S., Nakamichi, S., Aloisio, S., Hashimoto, S., and Kawasaki, M.: Temperature and pressure dependence study of the reaction of IO radicals with dimethyl sulfide by cavity ringdown laser spectroscopy, J. Phys. Chem. A, 107, 6381-6387, 2003.

Peixoto, J. P. and Oort, A. H.: Physics of Climate, American Institute of Physics, New York, 1991.

Pszenny, A. A. P., Moldanova, J., Keene, W. C., Sander, R., Maben, J. R., Martinez, M., Crutzen, P. J., Perner, D., and Prinn, R. G.: Halogen cycling and aerosol $\mathrm{pH}$ in the Hawaiian marine boundary layer, Atmos. Chem. Phys., 4, 147-168, 2004.

Rancher, J. and Kritz, M. A.: Diurnal fluctuations of Br and I in the tropical marine atmosphere, J. Geophys. Res., 85, 5581-5587, 1980.

Ross, A. B., Mallard, W. G., Helman, W. P., Buxton, G. V., Huie, R. E., and Neta, P.: NDRL-NIST Solution kinetics database: Version 3.0, Notre Dame Radiation Laboratory, Notre Dame, and National Institut of Standards and Technology, Gaithersburg, 1998.

Saiz-Lopez, A., Plane, J. M. C., and Shillito, J. A.: Bromine oxide in the mid-latitude marine boundary layer, Geophys. Res. Lett., 31, doi: 10.1029/2003GL018 956, 2004.

Saltzman, E. S., Savoie, D. L., Prospero, J. M., and Zika, R. G.: Methane sulfonic acid and non-sea-salt sulphate in Pacific air: Regional and seasonal variations, J. Atmos. Chem., 4, 227-240, 1986.

Sander, R. and Crutzen, P. J.: Model study indicating halogen activation and ozone destruction in polluted air masses transported to the sea, J. Geophys. Res., 101, 9121-9138, 1996.

Sander, R., Keene, W. C., Pszenny, A. A. P., Arimoto, R., Ayers, G. P., Baboukas, E., Cainey, J. M., Crutzen, P. J., Duce, R. A., Hönninger, G., Huebert, B. J., Maenhaut, W., Mihalopoulos, N., Turekian, V. C., and Dingenen, R. V.: Inorganic bromine compounds in the marine boundary layer: A critical review, Atmos. Chem. Phys., 3, 1301-1336, 2003.

Sciare, J., Baboukas, E., and Mihalopoulos, N.: Short-term variability of atmospheric DMS and its oxidation products at Amsterdam Island during summer time, J. Atmos. Chem., 39, 281-302, 2001.

Sievering, H., Lerner, B., Slavich, J., Anderson, J., M. Posfai, M., and Cainey, J., $\mathrm{O}_{3}$ oxidation of $\mathrm{SO}_{2}$ in sea-salt aerosol water: 
Size distribution of non-sea-salt sulfate during the first aerosol characterization experiment (ACE 1), J. Geophys. Res., 104, 21707-21 717, 1999.

Toumi, R.: BrO as a sink for dimethylsulphide in the marine atmosphere, Geophys. Res. Lett., 21, 117-120, 1994.

Toyota, K., Kanaya, Y., Takahashi, M., and Akimoto, H.: A box model study on photochemical interactions between VOCs and reactive halogen species in the marine boundary layer, Atmos. Chem. Phys. Discuss., 3, 4549-4632, 2003.

Twomey, S.: Pollution and the planetary albedo, Atmos. Environ., 8, 1251-1256, 1974.

Urbanski, S., Stickel, R. E., and Wine, P. H.: Mechanistic and kinetic study of the gas-phase reaction of hydroxyl radical with dimethyl sulfoxide, J. Phys. Chem. A, 102, 10 522-10 529, 1998.

Vogt, R., Crutzen, P. J., and Sander, R.: A mechanism for halogen release from sea-salt aerosol in the remote marine boundary layer, Nature, 383, 327-330, 1996.

Vogt, R., Sander, R., von Glasow, R., and Crutzen, P.: Iodine chemistry and its role in halogen activation and ozone loss in the marine boundary layer: A model study, J. Atmos. Chem., 32, 375395, 1999.

von Glasow, R. and Crutzen, P. J.: Tropospheric halogen chemistry, in The Atmosphere, edited by Keeling, R. F., Vol. 4, Treatise on Geochemistry, edited by Holland, H. D. and Turekian, K. K., pp. 21-64, Elsevier-Pergamon, Oxford, 2003. von Glasow, R. and Sander, R.: Variation of sea salt aerosol $\mathrm{pH}$ with relative humidity, Geophys. Res. Lett., 28, 247-250, 2001.

von Glasow, R., Sander, R., Bott, A., and Crutzen, P. J.: Modeling halogen chemistry in the marine boundary layer. 1. Cloud-free MBL, J. Geophys. Res., 107, 4341, doi: 10.1029/2001JD000 942, 2002a.

von Glasow, R., Sander, R., Bott, A., and Crutzen, P. J.: Modeling halogen chemistry in the marine boundary layer. 2. Interactions with sulfur and cloud-covered MBL, J. Geophys. Res., 107, 4323, doi: 10.1029/2001JD000 943, 2002b.

Wagner, V., von Glasow, R., Fischer, H., and Crutzen, P. J.: Are $\mathrm{CH}_{2} \mathrm{O}$ measurements in the marine boundary layer suitable for testing the current understanding of $\mathrm{CH}_{4}$ photooxidation?, J. Geophys. Res., 107, 4029, doi: 10.1029/2001JD000 722, 2002.

Wang, L. and Zhang, J.: Ab initio study of reaction of dimethyl sulfoxide (DMSO) with OH radical, Chem. Phys. Lett., 356, 490496, 2002.

Watts, S. F. and Brimblecombe, P.: The henry law constant of dimethylsulfoxide, Environ. Technol. Lett., 8, 483-486, 1987.

Yin, F., Grosjean, D., and Seinfeld, J. H.: Photooxidation of dimethyl sulfide and dimethyl disulfide. I: Mechanism development, J. Atmos. Chem., 11, 309-364, 1990.

Zafiriou, O. C., McFarland, M., and Bromund, R. H.: Nitric oxide in seawater, Science, 207, 637-639, 1980. 